\title{
Towards GIS Mapping and Spatial Modelling of Archaeological Sites in the Southeast Queensland Bioregion
}

\author{
Mike Rowland and Malcolm Connolly \\ Environmental Protection Agency, PO Box 155, Albert Street, Brisbane, Queensland, 4002, Australia
}

\begin{abstract}
In the early 1980s a strategic approach to the description, assessment and management of cultural heritage places using biogeographical boundaries was developed in Queensland. A recent refinement correlates sites on the Environmental Protection Agency's Indigenous Sites Database with environmental variables for the Moreton Basin Province of the Southeast Queensland Bioregion. Archaeological sites in the province are correlated with distance to water, elevation and particular geological and vegetation types. These correlations may reflect either real relationships or biases in the data. Preliminary correlative models developed are not considered substitutes for further inventory surveys and ongoing model refinement. The development of such models is considered useful in providing initial understanding of site distribution patterns.
\end{abstract}

\section{Introduction}

Cultural heritage managers need to develop a proactive strategic focus. Such an objective requires an understanding of past human behaviour, past and present landscapes plus human impacts on them, and the strengths and weaknesses of current site databases. A strategic focus also requires the development of suitable modelling tools that incorporate both environmental and cultural factors. In all strategic approaches some kind of geographical, political or cultural boundary, or combination of such boundaries is used as a baseline to first characterise and then access the archaeological record. In Queensland, a strategic approach to the description, assessment and management of cultural heritage places using biogeographical boundaries was attempted in the early 1980s. It developed in response to a perception that any attempt to describe, let alone assess the significance of cultural resources at a State-wide scale would be extremely difficult (if not impossible) given Queensland's considerable area $\left(1.7\right.$ million $\left.\mathrm{km}^{2}\right)$. It was therefore considered necessary to focus on smaller scale divisions of this State, and the biogeographical zones of Stanton and Morgan (1977) provided the most practical broad firstorder level framework available at the time.

In this paper we review the development of archaeological site recording in Queensland and the establishment of the Indigenous Sites Database. We outline the development of the biogeographical approach employed and its relevance in assessing the archaeological record. Then, employing the biogeographical approach, we describe the distribution of Queensland's recorded archaeological sites and make some broad predictions about site distribution generally. Finally, we consider the Southeast Queensland Bioregion in some detail and develop a preliminary predictive model of site distribution for the Moreton Basin Province. At this preliminary stage we focus on environmental rather than cultural variables.

\section{Background}

Archaeological sites in Queensland were first provided State protection under provisions of the Aboriginal Relics Preservation Act 1967-76 ('the Relics Act'), although an Archaeology Branch was not established and staffed until 1971 (Sutcliffe 1979). From 1971 to $1983,2,518$ sites were recorded, representing an average rate of 210 per year. The general public, Aboriginal Rangers, amateurs and a few professional researchers recorded most of these sites. Not until the early 1980 s did professional consultants begin to record large numbers of sites as a result of developmentdriven surveys (only one report was received in 1975, and this number increased to only 20 by 1984). Contrary to expectation, the professional standard of site recording did not improve substantially from the 1980s. Furthermore, the State's site filing system was poorly organised and managed. The number of sites on record was also very small (2,518 as at May 1983). There was an apparent bias in the types of sites recorded (e.g. 34\% were rock art sites) and site distribution was geographically skewed (e.g. hundreds of sites were known for southeast Queensland but none in parts of western Queensland). In sum, the site recording system needed upgrading.

In an attempt to redress these shortcomings, one of the authors (MR) in his capacity of Field and Research Archaeologist to the State government, initiated the development of a more useable database in 1981. A first step was the design of a new series of site recording forms. After considerable discussion with a range of users the design of new forms was finalised in 1983 and while field experience suggested some modification was required, these forms have generally proven quite serviceable. Recently, changes have been made to the forms to render them compatible with new electronic databases. Late 1985 saw completion of the transfer of information from the old site cards to the new site forms and this mammoth undertaking enabled corrections of records to be made. Site information was then computerised through the use of the MINARK archaeological database developed by Ian Johnson. The biogeographical zonal system of Stanton and Morgan (1977) was also adopted and incorporated at this time. From 1989, despite much criticism, plans for new approaches, and new computer systems, the sites database remained largely as initially developed until the appointment of the second author (MC) in late 1999. In August 2000, a new database application was developed in Microsoft ${ }^{\circledR}$ Access that maintained the structure and logic of the manual site recording cards but included an up-todate XY coordinate system to allow site records to be linked to a Geographic Information System (GIS). 
It should be noted that the 'Relics Act' used the term 'relics' to refer to 'any Aboriginal remains and any trace, remains or handiwork within the State of Aboriginal culture'. Furthermore, one aim of the Act was 'to preserve the visible record of traditional Aboriginal achievement within the State', which was to be achieved in part by establishing a record of 'relics' that contained information 'that is above question' (Sutcliffe 1979:56). The Cultural Record (Landscapes Queensland and Queensland Estate) Act 1987 continued most provisions of the 'Relics Act', including an emphasis on 'archaeological sites', although definitions were broadened to some degree. Consequently, the present database is dominated by information on archaeological sites rather than by Aboriginal 'sites of significance'. While this 'archaeological paradigm' has been strongly criticised (e.g. Ellis 1994), for current purposes we simply recognise the problem and stress the limitations in the current database. In recent years Aboriginal communities, archaeologists and the Cultural Heritage Branch have together developed a broader more encompassing concept of cultural heritage - albeit the emphasis on archaeological sites remains (see Rowland 1984, 1986, 1989, 1991, 1995 for discussion).

\section{Rationale for Using a Biogeographical Approach}

It is not unusual to describe or characterise the cultural resources of regions. In Australia as elsewhere, there is a long history of attempts to divide the country into areas with common features of Aboriginal culture and archaeology (e.g. Berndt and Berndt 1977; Davidson 1928; Elkin 1964; Howitt 1889; McCarthy 1940; Mulvaney 1975; Peterson 1976; Ross 1981; Stanner 1965; Tindale 1974). More recent attempts at such cultural area delineation have been specifically aimed at providing a context for making management decisions (Blain and Davis 1984; Flood 1984; Hughes and Sullivan 1984; Witter 1984).

The size and nature of territorial boundaries among Aboriginal populations is argued to have been closely, but not deterministically, related to environmental productivity. Birdsell (1953, 1957, 1968, 1971, 1977) demonstrated the existence of a general gradient in territorial size, with the largest occurring in the central Australian arid zone and the smallest in the better-watered regions, including more fertile coastal areas. Birdsell and others (Dixon 1976; Tindale 1974) also pointed out that denser, more territorially-bounded populations resided in the latter zones. Although the views of Birdsell and Tindale may today be considered simplistic, at a broad level there are reasonable grounds for predicting that site distribution across the landscape, in many but not all cases, will correlate well with a range of biogeographical factors.

Cultural heritage managers continue to face the issue of assessing significance on a day-to-day basis. Significance can be assessed at a number of spatial and conceptual but non-exclusive levels. At a spatial level, it can be defined at the local, regional, national or international levels. The latter is recognised by nominations such as World Heritage listing, and the former categories by heritage reserves, National Parks and a variety of site-specific protection measures such as Designated Landscape Areas in Queensland and their equivalents in other Australian states. Cultural heritage values may also be assessed at many different conceptual levels of which the most important issue is the question: 'significant to whom, and for what reasons?' In the present discussion we generally focus on sites or places and their spatial association with environmental variables, not on the broader concept of cultural heritage significance that is currently under critical review (e.g. Smith 1996).

In Queensland, identifying heritage places considered to be of local, regional or national significance was, and to a degree remains an ad hoc process. In the 1980s Johnston and Rowland (1987) sought to develop a more formal process of assessment using a set of physical boundaries to describe and characterise Queensland's archaeological record and assess heritage significance at the regional level. The set of biogeographical boundaries they used was seen to provide a working model to upgrade knowledge of the distribution of Aboriginal archaeological sites throughout the State, and to develop a strategic program for site conservation. The broad biogeographical divisions of Stanton and Morgan (1977) were considered appropriate to provide a first-order level of analysis. It was anticipated that future studies would focus on smaller subregional divisions and that cultural, political and indeed any other boundaries considered appropriate could be incorporated into the analysis.

More recently, the Queensland bioregional classification has been used as a model for an interim biogeographical regionalisation for Australia (Thackway and Cresswell 1995). This regionalisation schema incorporates the 12 Stanton and Morgan (1977) bioregions but recognises that parts of five other regions are small extensions of bioregions in adjacent states and the Northern Territory. In addition, the latitudinally extensive Brigalow Belt bioregion has been split into two, reflecting the significant geological and climatic variation between its northern and southern parts. In total 19 bioregions, in whole or part, have now been recognised in Queensland (Sattler 1999:4). These boundary changes are not relevant to the issues raised in this paper but will be incorporated in later refinements.

In Australia, management archaeology in the 1980s relied heavily on the concept of representativeness in assessing the significance of archaeological sites (Bowdler 1981, 1983, 1984; Flood 1984; Witter 1984) although the definition of the spatial limits of representativeness were limited to discussions by Flood (1984), Blain and Davis (1984) and Witter (1984). The concept of representativeness rose to prominence in the Australian archaeological literature in 1981 when Bowdler identified it along with 'timely and specific research questions' as the two most important criteria in assessing the scientific significance of archaeological sites. Bowdler used a statistical definition by Lipe to define representativeness:

A representative sample is designed to represent a large population of items in terms of a small selection of such items, with a minimum bias in the selection (Lipe 1977:30, cited in Bowdler 1981:129).

This statistical definition was translated into a workable archaeological definition:

Representativeness is the degree to which sites in the investigated (perhaps threatened) area are representative of sites known elsewhere, and where they might be better protected (Bowdler 1981:128). 
Representativeness was thus defined largely as a tool for crisis management and assessment. The definition also contained an inherent problem since parameters of the sampling universe in archaeology are rarely known. For example, at the local and regional level it may be possible to obtain a 'representative' sample, but as the unit of analysis gets larger the reliability of the sample must inevitably be reduced. The problem was resolved to some degree when Bowdler introduced the notion of context into the definition of representativeness:

The assessment of representativeness itself must be in a context. For instance, it must be decided whether a scarred tree on the edge of a larger river is in a class represented by scarred tree on the edge of a small billabong; whether scarred box trees are in the same class as scarred red river gums; and so on (Bowdler 1983:40).

Context in this example is framed to include both archaeological and environmental factors in the form of the characteristics of the site type and its local environmental setting. Such site-specific cases of context are at a high level of resolution and underlie the concept of predictive modelling. A wider interpretation of the term 'context' that includes regional and national representativeness was used by Flood (1984) and Witter (1984) and was also used by Johnston and Rowland (1987) as a first-order level of analysis.

While not discounting cultural issues, Hughes and Sullivan $(1982,1984)$ proposed that the type, frequency and preservational potential of Australian Aboriginal archaeological sites is strongly correlated with the local environment and specifically with local bedrock geology, landforms, soils, vegetation and climate:

\begin{abstract}
These factors influenced the availability of plant and animal foods and other organic raw materials, water, raw materials for stone artefacts, suitable campsites, and landforms and rock surfaces upon which rock art could be executed. They also affected the ease with which people could travel across the land.

These environmental factors are also important in that they affect the degree to which sites have survived in the face of natural and human agencies of destruction, and they affect the likelihood of sites being detected by ground survey (Hughes and Sullivan 1984:34).
\end{abstract}

These views owe much to North American developments (Butzer 1971, 1982), particularly to sampling techniques based on ecological and geomorphic zones (Judge et al. 1975), and ultimately to Binford (1964:433) who defined the region as the unit most applicable to analysing populations of sites. Flood (1984) and Witter (1984) expanded the Hughes and Sullivan approach to a regional focus on the basis that similar environments should contain similar archaeological sites with similar site histories and preservation potentials. While Johnston and Rowland (1987) agreed with these views, neither Flood nor Witter's approach was considered practical in terms of application. Instead, they chose the biogeographical regions of Queensland as defined by Stanton and Morgan (1977) as they provided both broad and subdivided regions of the State and thus permitted some focus on each region and its subregions as might be required in the future. Stanton and Morgan (1977) aimed to define the major biomes and landscapes within Queensland so that the process of selecting areas for nature conservation would not confuse fundamentally different regions and thereby bias the process of preserving a diverse range of environments. The 12 regions defined were identified as those with essentially homogenous vegetation and landform. A small area on the New South Wales-Queensland border identified by Wills (1976) was also included as a distinct region. It was included in the Johnston and Rowland model as a thirteenth region in line with the Queensland National Parks and Wildlife Service (QNPWS) State biogeographical divisions (Sattler 1986). We note here that Johnston and Rowland were unaware when they made the decision to use Stanton and Morgan (1977) that the QNPWS were also using this regional system for basically similar reasons. The bioregional approach continues to be used by QNPWS and throughout the Environmental Protection Agency in general.

\section{Applications of the Biogeographical Approach}

In 1987 (as is still the case) there remained substantial areas of Queensland for which the basic outlines of human occupation had not been described. Thus, Johnston and Rowland (1987) recommended overviews of all biogeographical regions be undertaken to identify biases in site data and to establish guidelines for more informative survey, research and management objectives. Desk-based overviews of the Mitchell Grass Downs (MGDs) (Border and Rowland 1990) and the Desert Uplands (DUs) (Smith and Rowland 1991) were undertaken and, aside from achieving stated objectives, these reviews have been popular with some Aboriginal communities and other individuals because they provided basic introductions and summaries of the bioregions from which further independent research could be undertaken.

These overviews of the MGDs and DUs demonstrated the potential of the biogeographical approach to identify some obvious environmental patterns in site distribution patterns. They also enabled estimates of the relative stability of different land systems to be made and, as a consequence, permitted the assessment of the stability of different site types. Analysis of land systems also provided a basis for assessing site significance. For example, 51\% of sites recorded for the MGDs were located in creek and river flat systems, a fact that is consistent with ethnographic accounts that river and stream systems were the focus of economic activities. Surprisingly, $84 \%$ of sites recorded in the DUs fell in the Eucalypt Woodland Land System, a fact that is in disagreement with ethnography. This discordance may be due to small sample size, recorder bias or may be a real pattern that highlights the need for further investigation.

The studies also highlighted three significant characteristics of these regions that contrast with other biogeographical regions: relative isolation, small population size and limited development. As the MGDs are larger than Victoria, and the DUs are about the size of Tasmania, management strategies developed for these regions must be approached quite differently to those in other biogeographical zones. For example, development threats in these regions are quite localised and particular emphasis might best be placed on gaining community support and involvement of local landholders in issues of 
site preservation. By way of contrast, in the Southeast Queensland Bioregion it is obvious that a much more proactive survey strategy should be developed in response to high levels of population growth and rapid urban development (see Rowland et al. 1994 for detail). Border (1992) subsequently undertook a field survey of the Central Downs subregion of the MGDs, where no sites had previously been recorded. This study confirmed the prediction of the desk-based study that within the Central Downs subregion most sites would be located in Alluvial and Dissected Residual Land Systems. The nature and distribution of stone artefacts in this subregion could be defined and, although the area represents only $10 \%$ of the MGDs, between 2,000 and 140,000 sites are estimated to remain unrecorded for this subregion alone. The sites recorded by Border included major art sites, and as many as 50 more such sites are predicted to remain unrecorded in the Central Downs subregion. Although very generalised, these observations allow for further strategic thinking in respect to recording and management options in these bioregions. In particular, there is the potential to place the results of development-driven reports into a broader, more meaningful context.

\section{A Proactive Approach}

A key element in any strategic cultural heritage management strategy must be the development of a proactive survey strategy. When one of the authors (MR) was appointed Field and Research Archaeologist to the State government in 1981 there was some opportunity to undertake such surveys (though these occurred predominantly in the coastal zone). Although limited in scale such surveys contributed to a better understanding of site distribution patterns as well as broader theoretical research and management issues. They also provided a baseline for others to undertake more comprehensive work. Unfortunately, since 1989 a proactive site survey component has not been considered 'core business' of Queensland's Environmental Protection Agency (EPA).

Considerable time, effort and funding also went into the development of a proposed new sites database that never eventuated. Fortunately, an alternative sites database using Microsoft ${ }^{\circledR}$ Access and with links to a GIS has been developed since late 1999 following appointment of the second author (MC). Establishment of the Indigenous Sites Database (ISD) now invites a return to a review and assessment process that was underway but cut short in the early 1990s. More recently, the Cultural Heritage Branch has been incorporated into the Environmental Planning Division of the EPA which has provided a 'window of opportunity' to revive and reassess these initial approaches.

The EPA's ISD continues to significantly underestimate the information that is available regarding Indigenous places in Queensland. Further information exists in many locations and formats (e.g. State archives, other government departments, museums, a range of publications and, of course, with Indigenous people themselves). These sources need to be reviewed and the information added, where appropriate, to the ISD. It would also be advantageous to continue the biogeographical overviews as described above as they have the advantages of identifying the nature of regional archaeological records, particular preservation problems associated with those regions and particular environmental and human impacts on them. Specific management strategies can then be developed that are suited to the nature of the regions and developmentdriven surveys interpreted within a more meaningful context. However, there is also a need for the EPA to develop its own proactive rather than reactive site recording, assessment and monitoring program.

The impetus to 'redevelop' a more strategic focus can in part be attributed to the EPA's need to offer advice and assistance to local government on heritage issues following the introduction of the Integrated Planning Act 1997. It is unfortunate that a decade has been lost in developing a more strategic focus. On a more positive note however, the original bioregions of Stanton and Morgan (1977) have recently been refined (Morgan and Terrey 1990; Sattler 1986; Sattler and Williams 1999) as have the distinctive subregions (now called 'provinces'). Regional cultural heritage studies such as those undertaken for the Bowen Basin have also been completed and offer new methodologies to be incorporated into our own (see Godwin et al. 1999). Most importantly, the broader range of functionality in the ISD should in the long-term assist in the development of more sophisticated models of site distributions in Queensland.

We are now in a position to use the ISD and bioregional framework to firstly characterise or visualise the archaeology of the Queensland bioregions and secondly to develop predictive site locational models. In this paper we attempt to do this on a broad scale for Queensland and then more specifically for the Southeast Queensland Bioregion. Firstly, however we discuss briefly the concept of predictive modelling and some of the numerous problems encountered in trying to develop such regional models.

\section{Predictive Modelling}

The pursuit of predictive modelling is due to its promise in the areas of cost-effectiveness and planning utility (Kohler and Parker 1986:398). In December 1981, the United States Bureau of Land Management (BLM) issued an instructional memorandum encouraging the development and use of predictive modelling in cultural resource management. Among other things it was thought 'that the exercise will lead to a product that alleviates the cultural resource identification demands on BLM and industry, without creating an unacceptable risk to cultural resources' (Burford 1981, cited in Judge and Martin 1988:571). Attempts to meet this instruction were wide-ranging, resulting in the publication Quantifying the Present and Predicting the Past: Theory, Method, and Application of Archaeological Predictive Modeling (Judge and Sebastian 1988). This was a seminal work in predictive modelling though it must be stressed that predictive modelling has long been a part of archaeological theory and practice.

Predictive modelling has generated a great deal of methodological and theoretical controversy and continues to be of interest. For example, some (rather optimistically) see GIS as offering a powerful research tool destined to have as profound an effect on the field of archaeology as did the introduction of radiocarbon dating in the 1950s (Wescott 2000:1). On the other hand Ebert (2000:130) presents a number of significant (but overly pessimistic) contrary views. First, he reminds us that it is productive, explanatory thought, and not computers that can potentially 
raise predictive modelling above an anecdotal level. His even testier footnote to this point expresses the view that computers have so far been detrimental to analytical thinking and explanation. His brief paper is a sobering reminder of some of the pitfalls of predictive modelling and he concludes:

\begin{abstract}
So what is inductive predictive modelling worth? And what will it become, when perfected? My assessment is, not very much. Inductive predictive modelling, which seems antithetical to using ethnographic observation and theory to approach an explanatory basis for its "modelling", is not going to get any more accurate than it is right now, whether it is done with GIS or a stack of semitransparent map overlays on a light table. It focuses on the wrong units of analysis, sites rather than systems, and attempts to relate their locations to "environmental variables" which not only are probably not variables at all, but cannot be warranted by any theoretical argument to be effective predictors of the locations of components of systems across landscapes (Ebert 2000:133-134).
\end{abstract}

Ebert is not alone in these views; a number of archaeologists doubt the efficacy and value of prediction in archaeology and it is seen by some as an expensive exercise to discover the obvious (Kohler and Parker 1986:398). Others see predictive modelling as it is currently practiced to be environmentally-deterministic, but this is a view that can rarely be substantiated (for a useful general critic see Coones 1992). Gaffney and van Leusen (1995) provide a useful summary of the debate over the use of environmental versus cultural factors and there is no doubt that certain environmental features and certain aspects of human behaviour do correlate well (Kohler 1988:19-25).

In this debate it is useful to provide a definition of a predictive model. A useful and long-standing definition is, 'hypotheses or sets of hypotheses which simplify complex observations whilst offering a largely accurate predictive framework structuring these observations' (Clarke 1968:32). All models by definition have predictive content, and thus the term 'predictive modelling' is in fact somewhat redundant, nevertheless it is widely used. All models are selective abstractions, which of necessity omit an explicit amount of the complexity of the real world. They also reflect to a considerable degree, subjectivity on the part of the observer. As Sebastian and Judge (1988:4) note, correlative predictive models are those that 'identify and quantify relationships between archaeological site locations and environmental variables' whereas explanatory models 'are deductively derived and attempt to predict how particular patterns of human use will be reflected in the archaeological record'. In reality the distinction between deductive and inductive models is to some degree a false dichotomy. The process of model building and refinement is based on a continuous cycle of data collection, analysis, and model refinement. Thus the results of field-testing and analysis are used to refine a model, which then guides the next phase of data collection. The eventual merging of deductive and inductive strategies offers the most positive future direction for cultural resource management (Kincaid 1988:565-566). Modelling is most useful as a long-term technique for organising and structuring data and data collection priorities. It is considerably less useful in the short-term where the situation does not allow for testing or refinement phases (Kincaid 1988:552).

No matter how carefully designed, methodologically sophisticated and thoroughly tested a correlative model is, the end product is nevertheless a series of statements about correlations between the occurrence of cultural remains and parameters or combinations of parameters of predominately modern environments, not generally ones that have changed over the last 40,000 years. Correlation tells us little if nothing about causality. Explanatory models on the other hand are extremely complex and difficult to build. Nevertheless, scientific explanation consists of theories or statements about the way that we believe the world operates and it is the nature of science to accept that a model may be wrong and in need of refinement or modification (Sebastian and Judge 1988:5-7).

The most useful locational models should be those that not only predict where sites are located but also explain why they are located where they are. Failure to take into account depositional and post-depositional processes will lead to predictive models that at best predict where sites have been seen and not necessarily where they are or were. First attempts at modelling will probably not provide high levels of prediction. They will not be substitutes for inventory surveys, and perhaps will not be good planning tools. In the long run, however, modelling may provide a heritage agency with useful tools to guide future development and management of cultural resources (Altschul 1988).

The EPA's existing ISD forms a large and underutilised body of information. It represents the cumulative effort of at least three decades of archaeological work, some performed at considerable cost. In some cases it may be that the existing data are well distributed throughout a region of study and are 'approximately representative' of a region's archaeology. However, in most cases existing archaeological data do not constitute a representative sample of the archaeological remains in a region. Different field projects, archaeologists, and field crews perform fieldwork and define, identify, and record archaeological sites in different ways and thus introduce sources of variation, bias and inconsistency (see Kvamme 1988). Most archaeologists would argue that random samples of site survey data (collected on the basis of regional probabilistic sampling designs) are necessary to make truly valid region-wide generalisations. But new surveys are expensive and resources are limited so there is perceived to be value in attempting to develop predictive models.

In this paper we take the view that there exists for Queensland and the Southeast Queensland Bioregion a large and under-utilised body of site information that can be analysed in conjunction with GIS to at least broadly describe or visualise the archaeology of Queensland. Secondly, while we accept many of the criticisms and limitations of predictive modelling noted above we take the view that development of preliminary correlative models may lead to some understanding of the distribution of sites within the Southeast Queensland Bioregion. We also accept that predictive models will not be a substitute for further inventory surveys and ongoing refinement of models. We acknowledge the debate concerning the definition of archaeological sites (e.g. Binford 1992; Dunnell 1992) but do not pursue it here. We also recognise 
Table 1. Bioregions of Queensland.

\begin{tabular}{|l|r|r|r|}
\hline \multicolumn{1}{|c|}{ Bioregion } & Regional Area $\left.\mathbf{( k m}^{\mathbf{2}}\right)$ & No. of Provinces & No. of Regional Ecosystems \\
\hline Northwest Highlands & 72237.89 & 4 & 41 \\
\hline Gulf Plains & 218915.88 & 10 & 83 \\
\hline Cape York Peninsula & 121623.81 & 9 & 211 \\
\hline Mitchell Grass Downs & 240913.7 & 7 & 53 \\
\hline Channel Country & 236597.69 & 10 & 56 \\
\hline Mulga Lands & 185260.71 & 10 & 66 \\
\hline Wet Tropics & 19909.39 & 9 & 105 \\
\hline Central Queensland Coast & 14466.61 & 5 & 37 \\
\hline Einasleigh Uplands & 118888 & 6 & 46 \\
\hline Desert Uplands & 70505.76 & 3 & 58 \\
\hline Brigalow Belt & 364732.9 & 36 & 163 \\
\hline Southeast Queensland & 61856.35 & 10 & 145 \\
\hline New England Tableland & 7729.97 & 3 & 21 \\
\hline TOTAL & 1733638.66 & 122 & 1085 \\
\hline
\end{tabular}

the need to eliminate data of questionable quality but believe that predictive modelling using GIS may partly assist in this process. Our approach is to correlate site locations with environmental variables or combinations of environmental variables. The approach is an attempt to search for patterns in the existing data that with subsequent field-testing and model refinement might assist in explaining and predicting site distributions. At a minimum the results should provide some strategic direction for cultural resource management issues in the region. We explore the relationship between site location and environmental variables so that our results generally fall short of explaining these relationships and leave that to future model developments.

\section{The Bioregions of Queensland}

Bioregions are based on broad landscape patterns that reflect major structural geological units, climate, as well as major floristic and faunistic assemblages. Thirteen are recognised for Queensland (Figure 1 and Table 1). Provinces delineate significant differences in each bioregion, usually associated with geology and geomorphology or finer climatic differences. The provinces therefore have a characteristic pattern of landform and vegetation and generally indicate major differences in land processes, energy budgets and species distributions. The definition of provinces has varied according to the availability of data (Sattler 1999:7). In the case of southeast Queensland a computer analysis of climate, terrain and substrate has been used to define 10 provinces (Young and Cotterell 1993) (see Figure 2 and Table 2). Land zones are a further level of classification and represent significant differences in geology and associated landforms, soils and physical processes that gave rise to distinctive landforms or continue to shape them. Generally speaking, land zones correspond to broad geological categories or groupings of these and can be readily identified on geological maps. Twelve land zones are recognised in Queensland, all but two of which are represented in the Southeast Queensland Bioregion. A finer level of environmental distinction is a regional ecosystem, which is a vegetation community in a bioregion that is consistently associated with a particular combination of geology, landform and soil. A total of 145 regional ecosystems are recognised for the Southeast Queensland Bioregion. Due to their complexity, neither the land zones nor the regional ecosystems are mapped here, although the relevant maps are available from the authors. In this paper we use bioregions and provinces as our units of analysis, giving consideration to their utility in first defining archaeological site distributions and in subsequently providing a basis for predictive modelling. We first characterise the archaeology of Queensland as a whole and then attempt the same for the Southeast Queensland Bioregion in more detail. Finally the potential and problems of predictive modelling are discussed using the Moreton Basin Province as an example.

Characterising or Visualising the Distribution of Archaeological Sites in Queensland

Before discussing archaeological site distribution, it is important to note some of the limitations of data used in this analysis. First, the 'site type' category is recorded on the ISD as either 'open' or 'cave/rockshelter'. These site types are then further defined as containing one or more of 19 'site attributes', including an 'other' category for sites that fail to fit into any of the predefined attribute categories. We recognise that the site classification system therefore creates problems for the types of generalisations 


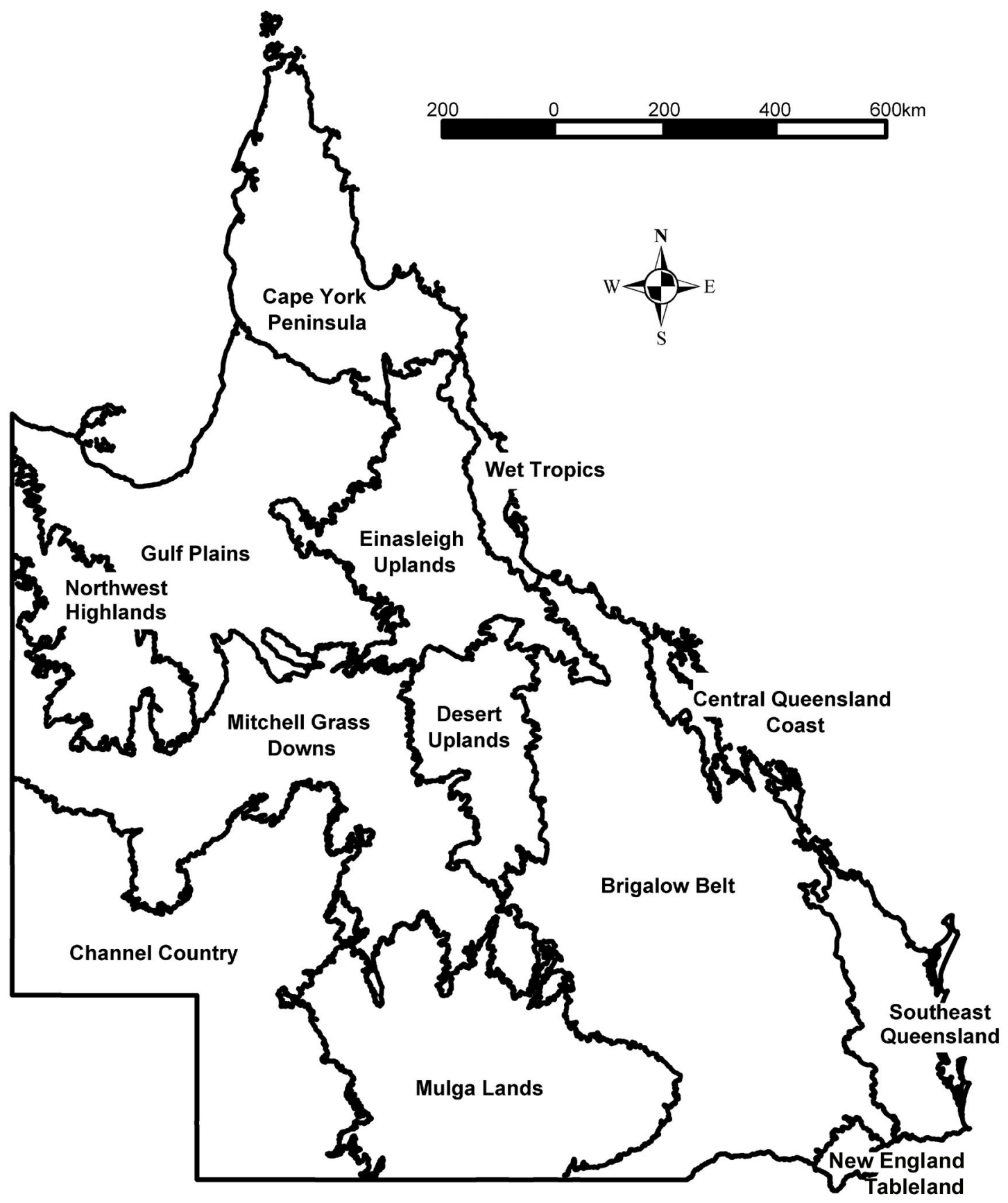

Figure 1. Queensland bioregions.

made in this paper. The 'other' category for example, includes a large range of site types and rationalisation of this category will therefore have to be undertaken if we wish to make more accurate generalisations of the type made in this paper. Second, the ISD includes only those sites reported to the EPA. We are aware of many unreported sites and that additional sites are described in a range of publications. We are currently in the process of locating and listing these sites on the ISD. For example, between March 2000 and August 2001 around 5,500 sites were added to the database.

Figure 3 shows the distribution of archaeological sites (which may have more than one attribute) recorded for Queensland (approximately 14,500 at August 2001). We suggest this indicates a significant interest in coastal sites (driven both by research and coastal development), though this is less marked in Cape York and the Gulf Country. There has also been a marked interest in rock art sites (e.g. Carnarvon Gorge, Northwest Highlands, Laura). More recently an increasing number of sites have been recorded as a result of large-scale infrastructural developments (e.g. noticeable are pipeline and other linear corridor surveys). There is also an apparent concentration of surveys in areas adjacent to the two major teaching universities in archaeology in Queensland (i.e. Brisbane and Townsville). Readers may draw similar broad generalisations from this map. It is also reasonable to infer that the number of sites on the ISD is a gross underestimation of extant sites. Unfortunately, at this point in time and given the variable quality of the data we are not in a position to even suggest 


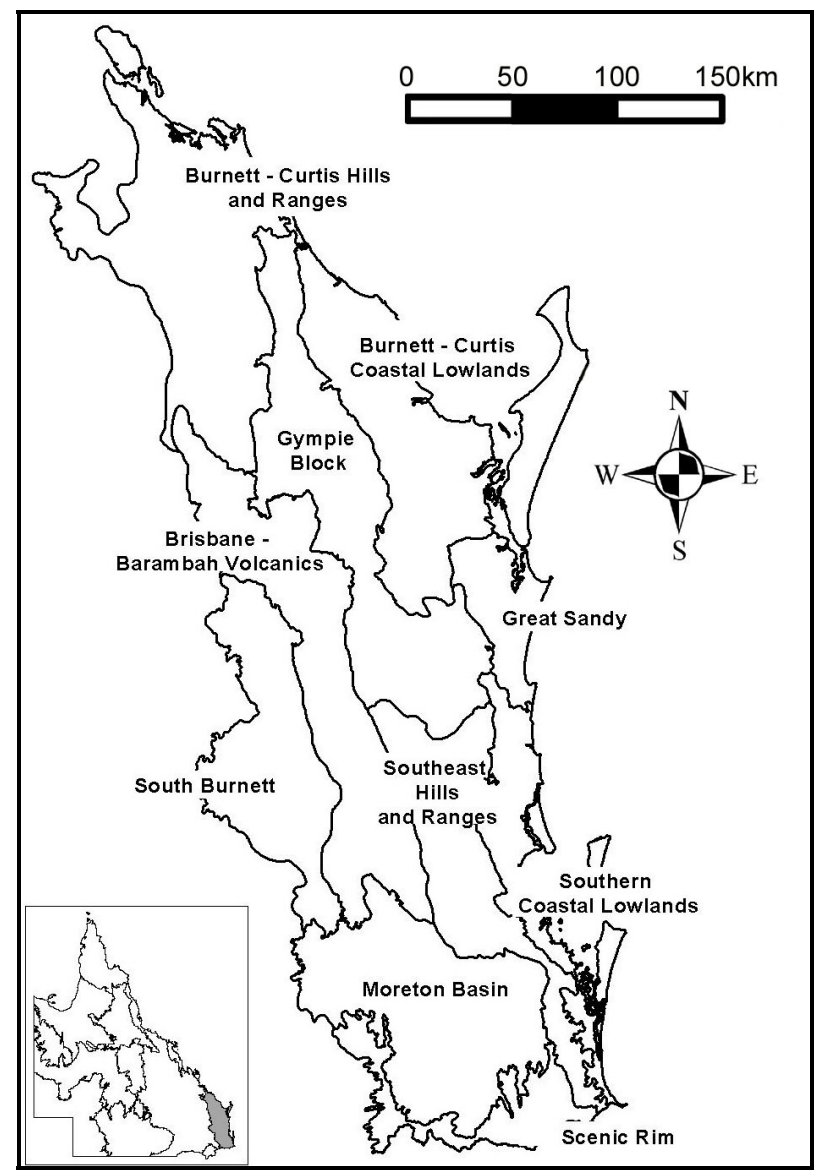

Figure 2. Southeast Queensland provinces.

some orders of magnitude of potential site numbers. We note, however, that Cane (1997), who undertook an Australia-wide assessment of coastal sites, estimated an average of 1 site $/ \mathrm{km}$ of coastline. If this were the case for Queensland then we should have at least 10,000 coastal sites recorded on the ISD. Finally, at this point in time there has been no systematic archaeological survey undertaken in Queensland that could be considered a regional survey in any broad geographical sense. This fact could be used to argue that attempts to produce predictive models are premature; equally however it could be used to argue in support of commencing the process.

Table 3 portrays the number of sites recorded per bioregion along with the percentage of the total that they represent. Most sites are recorded in the Brigalow Belt (28\%) followed by Southeast Queensland (19\%). All other regions are represented by $10 \%$ or less of recorded sites. However, because we must take bioregion area into account, site distribution is also depicted as sites $/ \mathrm{km}^{2}$ for each bioregion - and demonstrates a somewhat different distribution pattern. While most sites have been recorded in the Brigalow Belt, when bioregion area is taken into account, the coastal areas of Southeast Queensland (0.044 sites $\left./ \mathrm{km}^{2}\right)$, the Wet Tropics $\left(0.035\right.$ sites $\left./ \mathrm{km}^{2}\right)$ and the Central Queensland Coast $\left(0.015\right.$ sites $\left./ \mathrm{km}^{2}\right)$ appear to have been better surveyed. The only inland bioregion with a relatively high density of sites is the Northwest Highlands $\left(0.018\right.$ sites $\left./ \mathrm{km}^{2}\right)$. The highest value of 0.044 sites $/ \mathrm{km}^{2}$ for Southeast Queensland and the lowest of $0.002 \mathrm{sites} / \mathrm{km}^{2}$ for the Mitchell Grass Downs suggest that none of the bioregions have been adequately surveyed. As noted above
Border (1992) estimated somewhere between 2,000 and 140,000 sites remain unrecorded for the Central Downs (which represents $10 \%$ of the bioregion) subregion of the Mitchell Grass Downs. We have insufficient information available on which to make further estimates of orders of magnitude.

Table 3 also shows the most common site attribute recorded for each bioregion by percentage and demonstrates that for all inland bioregions the most common recorded site type is Artefact Scatters. The results are marked since in these bioregions they represent between $42 \%$ and $72 \%$ of all sites. This consistent pattern throughout all inland bioregions would tend to suggest that it was a real pattern and less likely to be affected by recorder bias, but we currently have no way of testing this inference. The predominance of Art Sites (63\%) in Cape York Peninsula is probably due to recorder bias and is unlikely to be representative of the range of site types to be found in that region. In both the Central Queensland Coast (58\%) and Southeast Queensland bioregions (44\%) the dominant site type is Shell Middens. This site type is probably also over-represented in these regions but since they are better surveyed, these figures may begin to approximate the type of site likely to be found in the region (although again we have no way of currently assessing this assumption). The Wet Tropics (32\%) and New England Tablelands (44\%) are dominated by the category 'Other'. As noted above, there are problems in using this category and it is probable that it simply reflects a low level of recording in these areas.

Table 3 also shows the second-most recorded site per bioregion as a percentage of the total. A clear pattern emerges with the Northwest Highlands (21\%), the Gulf Plains (34\%), the Einasleigh Uplands (39\%), Desert Uplands (26\%) and Brigalow Belt (24\%) having a predominance of Art Sites. Recorder bias must again be significant in these cases and we do know that within these regions rock art is common only in certain localities. Shell Middens are the second most recorded site in Cape York Peninsula (27\%). In the Wet Tropics (28\%), Central Queensland Coast (30\%) and Southeast Queensland (40\%) Artefact Scatters are the second-most recorded sites. In the Mitchell Grass Downs, the fact that Hearths (16\%) are the second-most recorded site must reflect small sample size and/or recorder bias since this is generally not a common site type. In both the Channel Country (20\%) and Mulga Lands (16\%) stone arrangements are the second-most recorded site and this again highlights that recorder bias and small sample size may be significant in accounting for the pattern.

\section{Summary}

While we have provided the distribution of sites and site types for the various bioregions of Queensland, survey coverage has been so limited that little more than the broadest generalisations can be made for each bioregion. It is clear that the ubiquitous site type Artefact Scatters predominates in all inland bioregions and is the secondmost recorded site in all coastal bioregions. However, because there have been no substantial systematic geographically based studies we are unable at this stage to determine to what extent recorder bias, sample size or other factors may have determined these patterns. Nevertheless, 
Table 2. Provinces of the Southeast Queensland Bioregion (Young and Dillewaard 1999).

\begin{tabular}{|c|c|c|c|c|c|}
\hline Province & Geology & Landform/s & $\begin{array}{l}\text { Annual Rainfall } \\
\text { (mm) }\end{array}$ & Vegetation & $\begin{array}{c}\text { Elevation } \\
\text { (m) }\end{array}$ \\
\hline Scenic Rim & $\begin{array}{l}\text { Basic, intermediate } \\
\text { and acid volcanics and } \\
\text { small areas of } \\
\text { sedimentary rocks }\end{array}$ & Plateaus and ranges & 1300 & $\begin{array}{l}\text { Notophyll } \\
\text { rainforest, tall } \\
\text { eucalypt }\end{array}$ & 700 \\
\hline Moreton Basin & $\begin{array}{l}\text { Fine and coarse- } \\
\text { grained sediments, } \\
\text { alluvium, localised } \\
\text { acid volcanic } \\
\text { intrusions }\end{array}$ & $\begin{array}{l}\text { Valleys and low } \\
\text { rolling hills }\end{array}$ & 850 & $\begin{array}{l}\text { Forest red gum } \\
\text { and ironbark } \\
\text { woodlands, vine } \\
\text { thicket, small } \\
\text { areas of brigalow } \\
\text { forest }\end{array}$ & 150 \\
\hline $\begin{array}{l}\text { Southeast Hills and } \\
\text { Ranges }\end{array}$ & $\begin{array}{l}\text { Metamorphics, } \\
\text { localised acid volcanic } \\
\text { intrusions, basic } \\
\text { volcanics }\end{array}$ & $\begin{array}{l}\text { Hills and ranges, } \\
\text { narrow alluvial } \\
\text { valleys }\end{array}$ & 1100 & $\begin{array}{l}\text { Tall mixed } \\
\text { eucalypt forests, } \\
\text { notophyll }\end{array}$ & 250 \\
\hline $\begin{array}{l}\text { Southern Coastal } \\
\text { Lowlands }\end{array}$ & $\begin{array}{l}\text { Coastal and estuarine } \\
\text { sediments, fine and } \\
\text { coarse-grained } \\
\text { sedimentary rocks }\end{array}$ & $\begin{array}{l}\text { Coastal plain and } \\
\text { low hills }\end{array}$ & 1500 & $\begin{array}{l}\text { Eucalypt, } \\
\text { localised forest, } \\
\text { woodlands, } \\
\text { shrublands }\end{array}$ & 25 \\
\hline $\begin{array}{l}\text { Brisbane-Barambah } \\
\text { Volcanics }\end{array}$ & $\begin{array}{l}\text { Acid volcanics, } \\
\text { sediments, } \\
\text { metamorphics, minor } \\
\text { basic volcanics, } \\
\text { alluvium }\end{array}$ & $\begin{array}{l}\text { Rolling hills, broad } \\
\text { alluvial valleys }\end{array}$ & 800 & $\begin{array}{l}\text { Forest red gum } \\
\text { and ironbark } \\
\text { woodlands, } \\
\text { araucarian } \\
\text { rainforest }\end{array}$ & 200 \\
\hline South Burnett & $\begin{array}{l}\text { Basic volcanics, old } \\
\text { land surfaces with } \\
\text { laterite, fine-grained } \\
\text { sediments, localised } \\
\text { acid volcanic } \\
\text { intrusions }\end{array}$ & $\begin{array}{l}\text { Plateaus and rolling } \\
\text { hills }\end{array}$ & 750 & $\begin{array}{l}\text { Ironbark, gum- } \\
\text { topped box } \\
\text { forest and } \\
\text { woodlands, } \\
\text { araucarian } \\
\text { rainforest }\end{array}$ & 400 \\
\hline Gympie Block & $\begin{array}{l}\text { Metamorphics, old } \\
\text { sediments, basic and } \\
\text { intermediate } \\
\text { volcanics, acid } \\
\text { volcanic intrusions, } \\
\text { alluvium }\end{array}$ & $\begin{array}{l}\text { Rolling hills, alluvial } \\
\text { valleys }\end{array}$ & 1000 & $\begin{array}{l}\text { Mixed eucalypt } \\
\text { forests, ironbark } \\
\text { and spotted gum } \\
\text { woodlands, } \\
\text { araucarian } \\
\text { rainforest }\end{array}$ & 150 \\
\hline $\begin{array}{l}\text { Burnett-Curtis } \\
\text { Coastal Lowlands }\end{array}$ & $\begin{array}{l}\text { Fine-grained } \\
\text { sediments, often } \\
\text { duricrusted, alluvium, } \\
\text { coastal and estuarine } \\
\text { sediments }\end{array}$ & Broad coastal plain & 1100 & $\begin{array}{l}\text { Eucalypt and } \\
\text { melaleuca forest } \\
\text { and woodlands }\end{array}$ & 50 \\
\hline Great Sandy & $\begin{array}{l}\text { Dune sands, fine- } \\
\text { grained sediments }\end{array}$ & $\begin{array}{l}\text { Sand dunes and } \\
\text { plains }\end{array}$ & 1400 & $\begin{array}{l}\text { Syncarpia, } \\
\text { Lophostemon } \\
\text { tall forests, } \\
\text { eucalypt, banksia } \\
\text { forests, } \\
\text { woodlands and } \\
\text { shrublands }\end{array}$ & 25 \\
\hline $\begin{array}{l}\text { Burnett-Curtis Hills } \\
\text { and Ranges }\end{array}$ & $\begin{array}{l}\text { Acid volcanics, } \\
\text { metamorphics, } \\
\text { localised basic } \\
\text { volcanics, small areas } \\
\text { of elevated sediments }\end{array}$ & $\begin{array}{l}\text { Hills and ranges, } \\
\text { alluvial valleys }\end{array}$ & 900 & $\begin{array}{l}\text { Ironbark, lemon- } \\
\text { scented gum and } \\
\text { forest red gum } \\
\text { woodlands, } \\
\text { araucarian } \\
\text { rainforest }\end{array}$ & 250 \\
\hline
\end{tabular}


Table 3. Distribution of archaeological sites by bioregions.

\begin{tabular}{|l|r|r|r|l|r|l|r|}
\hline \multicolumn{1}{|c|}{ Bioregion } & \multicolumn{1}{|c|}{$\begin{array}{c}\text { No. of } \\
\text { Sites }\end{array}$} & $\begin{array}{c}\text { \%of } \\
\text { Total }\end{array}$ & Sites/km² & $\begin{array}{l}\text { Dominant Site } \\
\text { Attribute }\end{array}$ & $\begin{array}{c}\text { \% of } \\
\text { Total } \\
\text { Sites }\end{array}$ & $\begin{array}{c}\text { Second Site } \\
\text { Attribute }\end{array}$ & $\begin{array}{c}\text { \% of } \\
\text { Total } \\
\text { Sites }\end{array}$ \\
\hline Northwest Highlands & 1312 & 9 & 0.018 & Artefact Scatters & 57 & Art Sites & 21 \\
\hline Gulf Plains & 600 & 4 & 0.003 & Artefact Scatters & 46 & Art Sites & 34 \\
\hline Cape York Peninsula & 823 & 6 & 0.007 & Art Sites & 63 & Shell Middens & 27 \\
\hline Mitchell Grass Downs & 379 & 3 & 0.002 & Artefact Scatters & 72 & Hearths & 16 \\
\hline Channel Country & 1444 & 10 & 0.006 & Artefact Scatters & 71 & Stone Arrangements & 20 \\
\hline Mulga Lands & 707 & 6 & 0.004 & Artefact Scatters & 70 & Stone Arrangements & 16 \\
\hline Wet Tropics & 688 & 5 & 0.035 & Other & 32 & Artefact Scatters & 28 \\
\hline Central Queensland Coast & 221 & 2 & 0.015 & Shell Middens & 58 & Artefact Scatters & 30 \\
\hline Einasleigh Uplands & 892 & 6 & 0.008 & Artefact Scatters & 42 & Art Sites & 39 \\
\hline Desert Uplands & 219 & 2 & 0.003 & Artefact Scatters & 57 & Art Sites & 26 \\
\hline Brigalow Belt & 4103 & 28 & 0.011 & Artefact Scatters & 52 & Art Sites & 24 \\
\hline Southeast Queensland & 2706 & 19 & 0.044 & Shell Middens & 44 & Artefact Scatters & 40 \\
\hline New England Tableland & 43 & $>1$ & 0.006 & Other & 44 & Artefact Scatters & 16 \\
\hline
\end{tabular}

at a broad level we have provided a characterisation of each bioregion against which future surveys can be measured and modified. When these general overviews are combined with more detailed analysis, as was done in the case of the Mitchell Grass Downs (Border 1992; Border and Rowland 1990), and the Desert Uplands (Smith and Rowland 1991), the bioregions do provide a useful framework for analysis. In these cases we were able to characterise the archaeology of the bioregions, the extent of long- and short-term impacts in them and consequent management priorities. While Southeast Queensland has the highest recorded density of 0.044 sites $/ \mathrm{km}^{2}$, this figure probably underestimates the true number of sites existing in this region. It is on this bioregion that we now focus for our case study.

\section{Southeast Queensland Bioregion}

The coastal strip and adjacent hills and ranges of northern New South Wales and southern Queensland are among the richest of Australia's floral and faunal zones. The Southeast Queensland Bioregion occupies the northern part of this area and covers approximately $61,856.35 \mathrm{~km}^{2}$. It is characterised by moderate to high rainfall $(750-1500 \mathrm{~mm}$ per year) with a substantial winter component (up to $30 \%$ ), and warm to hot summers and cool winters. The major physiological features of the Southeast Queensland Bioregion are a coastal plain of varying width; hills and ranges; the major drainage basins of the Brisbane and Mary rivers, Barambah Creek, the lower Burnett River and coastal mainland and island sand masses. The latitude of Fraser Island is also the southern limit of distribution for a number of tropical species. It is the most densely populated part of Queensland with the population of the southern third of the bioregion predicted to increase by $100 \%$ to 3.8 million in the period 1991-2021 (Young and Dillewaard 1999). Again we attempt to describe site distribution in this bioregion before developing a predictive model for part of the region.

Figure 4 shows the Southeast Queensland Bioregion with province boundaries and recorded sites $(2,830$ at August 2001). It is obvious that sites are not evenly distributed, most sites being concentrated in the southeast, along the coast and particularly on the sand islands of South Stradbroke, North Stradbroke, Moreton and Bribie. It is also apparent that small numbers of sites have been recorded in a number of the provinces. This is demonstrated more clearly in Table 4 which shows that most sites have been recorded in the Southern Coastal Lowlands (43\%), followed by the Moreton Basin (14\%), and in the Southeast Hills and Ranges (9\%). The other seven provinces contain only $4-8 \%$ of recorded sites. Taking area into consideration, Table 4 shows a more marked predominance of sites in the Southern Coastal Lowlands $\left(0.331\right.$ sites $\left./ \mathrm{km}^{2}\right)$. Only the Great Sandy $(0.056$ sites $\left./ \mathrm{km}^{2}\right)$, Southeast Hills and Ranges $\left(0.046\right.$ sites $\left./ \mathrm{km}^{2}\right)$ and the Moreton Basin (0.047 sites $\left./ \mathrm{km}^{2}\right)$ provinces approach these densities. The Burnett-Curtis Hills and Ranges, Gympie Block and Brisbane-Barambah Volcanics have less than 0.015 sites $/ \mathrm{km}^{2}$. Given that we are looking for correlations between a range of sites and a range of environmental variables, only the Southern Coastal Lowlands, the Great Sandy, Southeast Hills and Ranges, and the Moreton Basin Province (4 out of 10) exhibit a recorded site density sufficient for the development of correlative predictive models. However, the relatively low site densities and uneven site distribution in these provinces do not provide sufficient data for more than very basic initial models. 


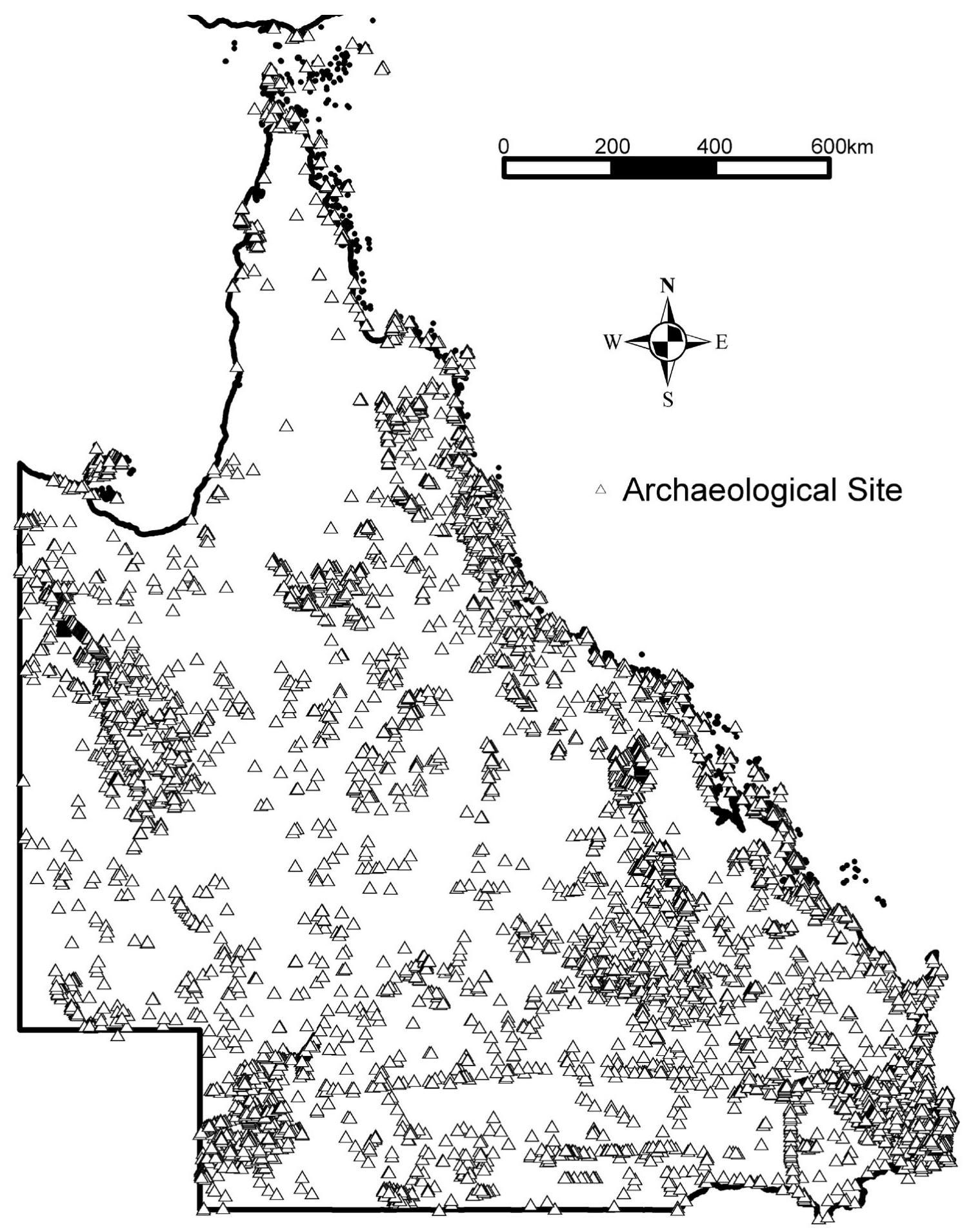

Figure 3. EPA Indigenous Sites Database: Distribution of recorded sites c.14,500 - August 2001).

Shell Midden sites dominate all coastal provinces (range $=47-74 \%$ ) while Artefact Scatter sites dominate the inland provinces except the Brisbane-Barambah Volcanics $($ range $=61-73 \%)$. This is the same general pattern noted for Queensland bioregions. The Brisbane-Barambah Province has a predominance of Scarred Tree sites (44\%), a fact probably reflecting no more than the low levels of recording in this area. Three of the four coastal provinces show a predominance of Artefact Scatter sites (range = 26-39\%) while Scarred Tree sites (22\%) dominate the Burnett-Curtis Coastal Lowlands. All inland provinces with the exception of South Burnett have a predominance of
'Other' sites (range $=14-35 \%$ ). South Burnett has a predominance of Scarred Tree sites (23\%). For the third and fourth most common site type, percentages are so low and diversity so great so that it is difficult to draw meaningful conclusions. However there are a number of first approximations that could provide some guidance in the field. For example, it would appear that there is a higher probability of finding art sites in the Gympie Block than any other province in the Southeast Queensland Bioregion. We now focus on the Moreton Basin Province in an attempt to develop a correlative model of archaeological site distribution. 


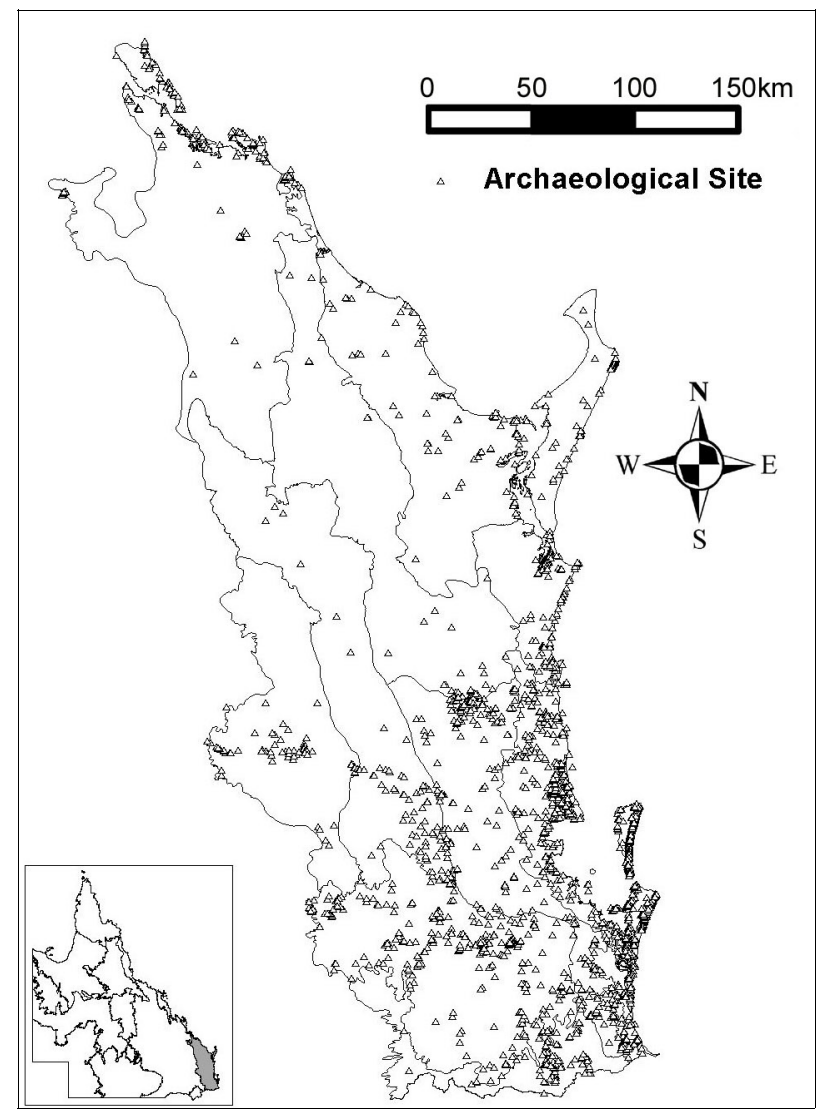

Figure 4. Southeast Queensland showing province boundaries and recorded sites (2,830 - August 2001).

\section{Moreton Basin Province}

The Moreton Basin is predominantly formed in Jurassic and Triassic-Jurassic sandstones. It is an area of low, hilly relief and broad alluvial valleys. Some parts are quite dry, with rainfall less than $750 \mathrm{~mm}$ per year. Major vegetation types include eucalypt woodlands and open forests, Acaia harpophylla open forest and semi-evergreen vine thickets (Young and Dillewaard 1999). The Moreton Basin Province (or part thereof) comprises the Albert, Bremer, Brisbane and Lockyer river drainage basins with low to hilly country in the east and high country abutting the Great Dividing Range in the west (Figure 5).

Although the Moreton Basin covers a relatively large area, it contains few recorded sites (372) (see Table 4) and sites located have been strongly influenced by the recording focus of cultural heritage consultants conducting Environmental Impact Assessments. Nevertheless, we have attempted to correlate certain environmental variables (geology, soils, vegetation, elevation, water) with site distribution in order to identify broader correlative patterns. At this stage we do not discriminate between site types and we include only data on the ISD. Obviously, more information on site location could be gleaned from various sources but to date time constraints have prevented such work. What follows is a first-order attempt to characterise the archaeological site distribution patterns of the Moreton Basin Province.

\section{Methods}

Identification of the distribution pattern of recorded archaeological sites in the Moreton Basin Province was undertaken in three stages. The first stage involved a simple correlation between the distribution of site types and underlying geology, soil types, vegetation, elevation and proximity to water. The second stage involved identifying the combinations of environmental variables containing the highest numbers of sites. The third stage involved the development of a simple predictive model using a Zonal Grid Analysis.

\section{Results}

\section{Geology and Site Distribution}

Figure 6 and Table 5 demonstrate that c.57\% of sites are located in Quaternary flood plains and river terraces (3975) and in areas of Jurassic sandstone, siltstone and shale (865). Geological categories containing no sites have for reasons of space been omitted from Table 5 but are available from the authors on request.

\section{Soils and Site Distribution}

Figure 7 and Table 6 demonstrate that c. $56 \%$ of sites are located in hard acidic yellow and red mottled soils (rolling to hilly terrain with gentle to moderate slopes - Tb64), hard acidic red and yellow soils (hilly sandstone country - P11), hard acidic and neutral soils (gently rolling areas of subcoastal lowlands - Tb65) and brown and grey cracking clays (terraced valley plains - MM9).

\section{Pre-Clearing Vegetation and Site Distribution}

Figure 8 and Table 7 demonstrate that c. $54 \%$ of sites are located in spotted gum/narrow-leaved ironbark woodland (H19) and blue gum flats woodlands (E10). Note that vegetation categories containing no sites have for reasons of space been omitted from Table 7 but are available from the authors.

\section{Elevation and Site Distribution}

Table 8 demonstrates that the majority of sites are located below $100 \mathrm{~m}$ elevation (c.57\%).

\section{Water and Site Distribution}

Tables 9 and 10 show the distribution of sites relative to water. Table 9 indicates that c. $62 \%$ of recorded sites are located near Stream Order 1 (those furthest from the main water source). However, this is actually not a significant correlation because there are 723 Order 1 streams. Six sites are located near Stream Order 6 and when ranked against the number of streams present, this correlation is most significant. Table 10 also indicates that c.50\% of sites are located within $200 \mathrm{~m}$ of water. However, since c. $40 \%$ of the land area of the province is within $200 \mathrm{~m}$ from water, by itself water cannot be used in this case as a strong predictor of site location.

Combined Environmental Variables and Site Distribution Figure 9 shows the combined environmental variables containing the highest number of sites in two groups. Group 1 (highest) shows the combinations of geology, soils and vegetation containing the most sites (Geology 865, Vegetation H19, Soils Gd4 - 22 sites and Geology 3975, Vegetation E10, Soils MM9 - 20 sites). Group 2 (high) shows the combinations with the second most recorded sites (Geology 3975, Vegetation E10, Soils Mm2 - 13 sites; Geology 865, Vegetation H19, Soils P11 - 12 sites and Geology 3975, Vegetation E9, Soils Kd6 - 12 sites). 


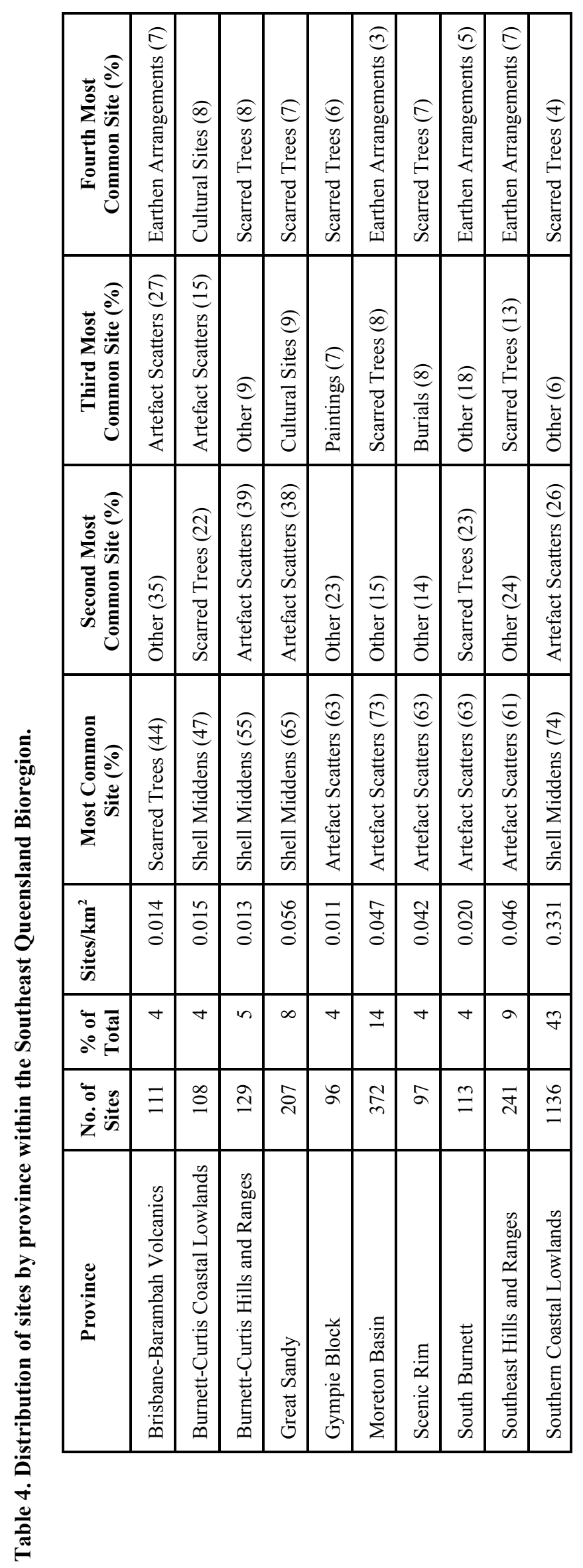




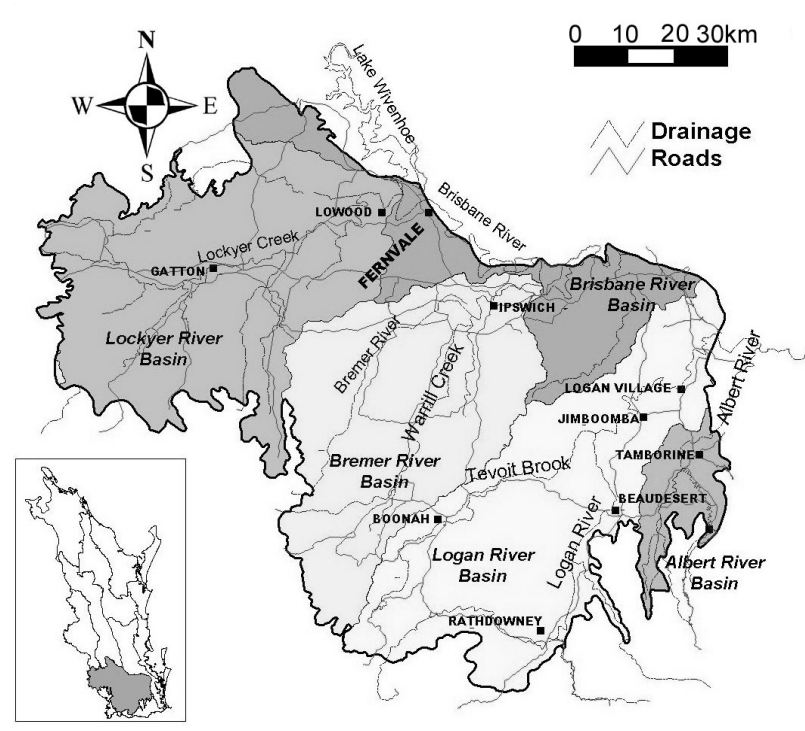

Figure 5. Moreton Basin Province study area.

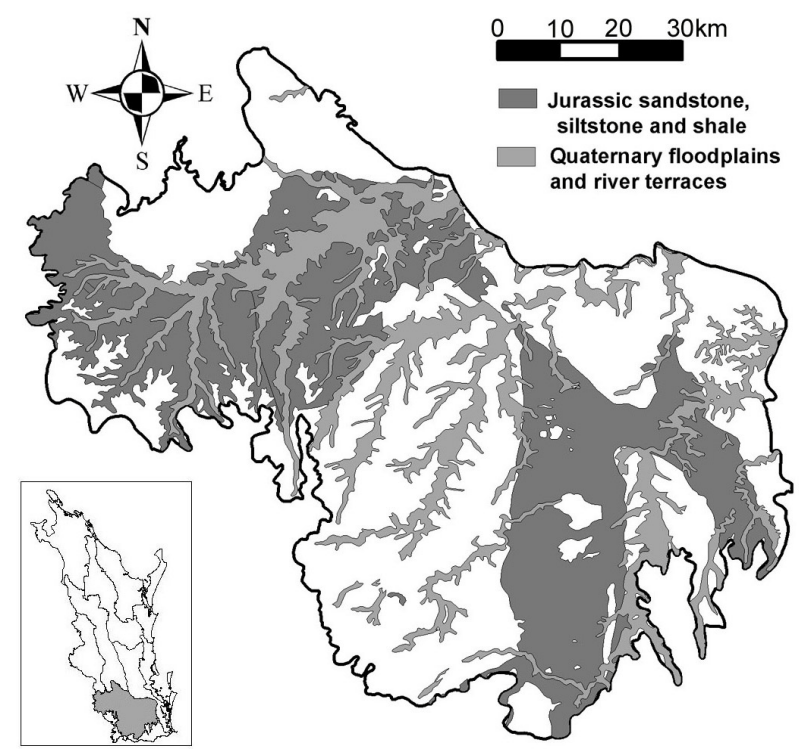

Figure 6. Moreton Basin Province: Geological units with a predominance of sites (c.57\%) (Department of Natural Resources and Mines, Geology 1:100,000 map sheet).

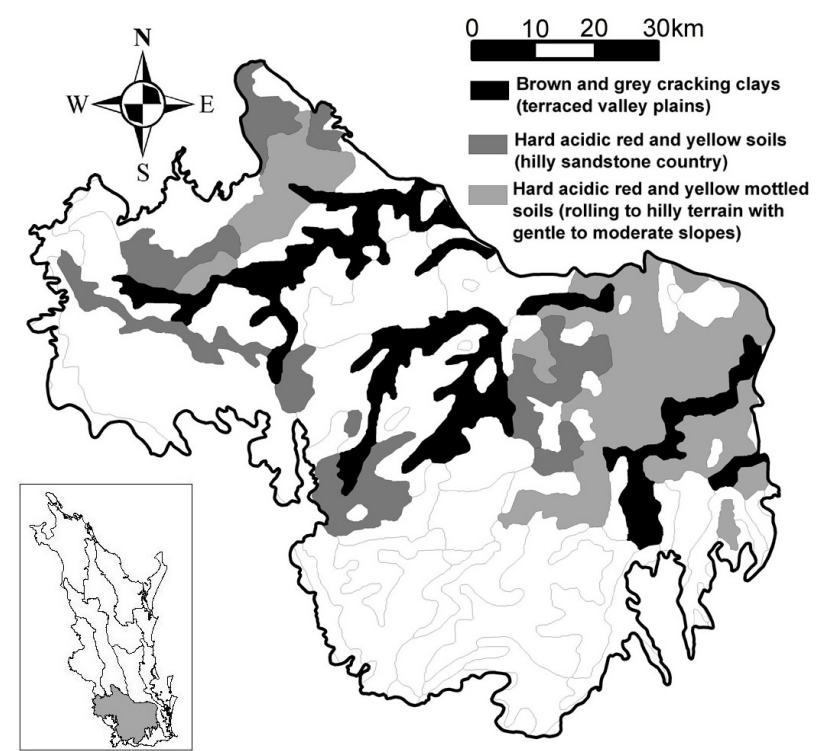

Figure 7. Moreton Basin Province: Soil units with a predominance of sites (c.56\%) (CSIRO Soils, 1999 1:2.5 million map).

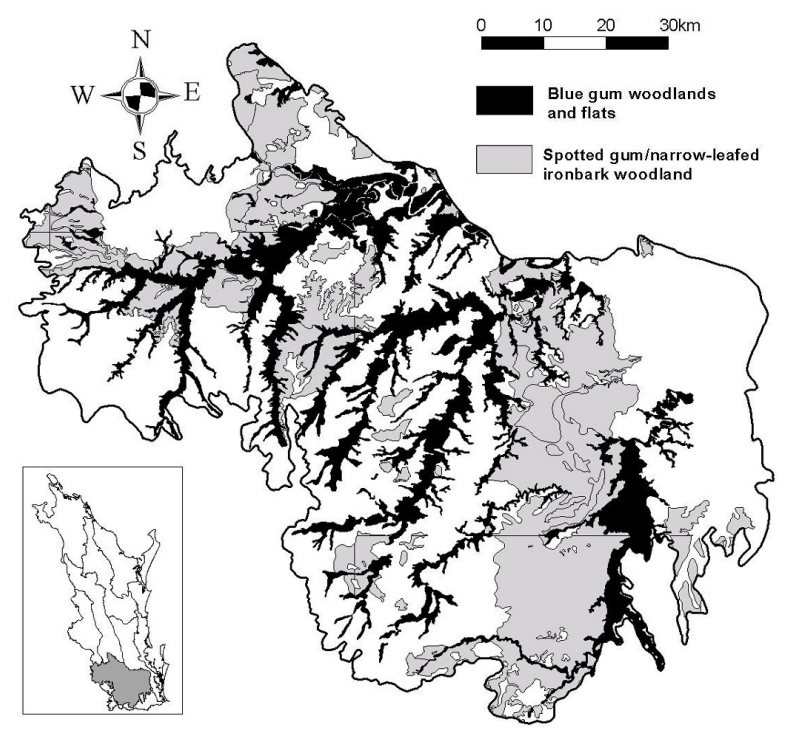

Figure 8. Moreton Basin Province: Vegetation units with a predominance of sites (c.54\%) (Queensland Herbarium, Pre-Clearing Vegetation 1:100,000 map sheet). 


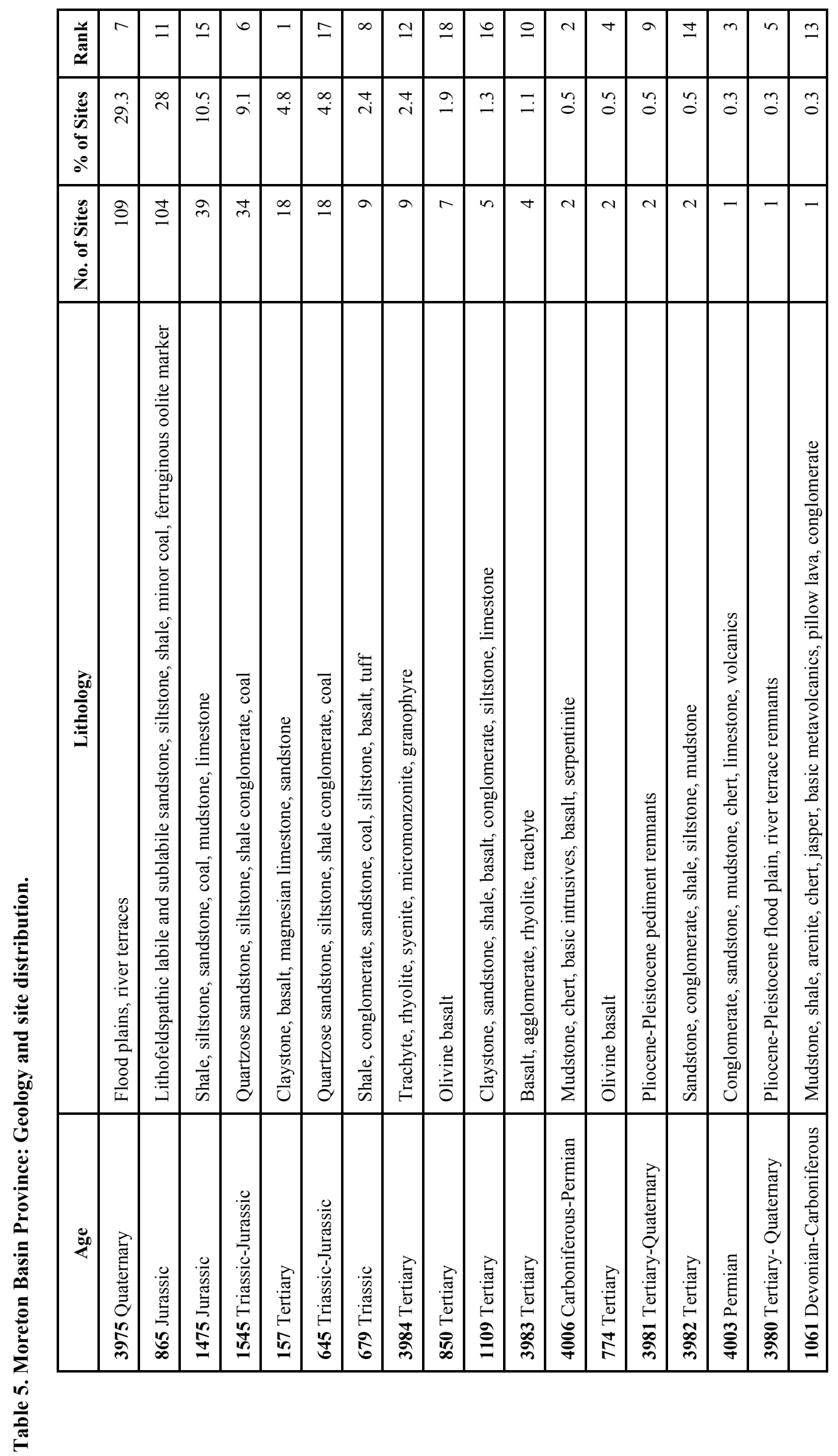


Table 6. Moreton Basin Province: Soils and site distribution.

\begin{tabular}{|c|c|c|c|}
\hline Soil Unit & $\begin{array}{l}\text { No. of } \\
\text { Sites }\end{array}$ & $\begin{array}{l}\% \text { of } \\
\text { Total }\end{array}$ & $\begin{array}{c}\text { Rank by } \\
\text { Area }\end{array}$ \\
\hline $\begin{array}{l}\text { Tb64 Rolling to hilly terrain with gentle to moderate slopes: chief soils } \\
\text { are hard acidic yellow and red mottled soils }\end{array}$ & 60 & 16.1 & 10 \\
\hline $\begin{array}{l}\text { P11 Hilly country of sandstones and intruded intermediate and basic } \\
\text { rocks, rising to } 800 \mathrm{ft} \text { above sea level: chief soils on the moderate to steep } \\
\text { slopes are hard acidic red and yellow soils }\end{array}$ & 59 & 15.9 & 12 \\
\hline $\begin{array}{l}\text { Tb65 Gently rolling areas of the sub-coastal lowlands (less than } 400 \mathrm{ft} \\
\text { above sea level) with a maximum relief of } 50 \mathrm{ft} \text { between crests and } \\
\text { valleys. The soil pattern is complex and controlled by the lithology of } \\
\text { parent rock material. Chief soils seem to be hard acidic and neutral } \\
\text { yellow and red soils, and on sandstones }\end{array}$ & 47 & 12.6 & 8 \\
\hline $\begin{array}{l}\text { MM9 Terraced valley plains: chief soils are brown and grey cracking } \\
\text { clays }\end{array}$ & 44 & 11.8 & 9 \\
\hline $\begin{array}{l}\text { Kb6 Rolling basaltic uplands: chief soils are dark cracking clays in } \\
\text { association with many other soils }\end{array}$ & 35 & 9.4 & 13 \\
\hline $\begin{array}{l}\text { Mm2 Strongly rolling to hilly country on calcareous sediments with } \\
\text { some steep-sided basaltic residuals: chief soils are alkaline friable earths } \\
\text { and soils with weak gilgai formation }\end{array}$ & 28 & 7.5 & 11 \\
\hline $\begin{array}{l}\text { Gd4 Steep hilly to submontane basaltic uplands: crests and steep slopes } \\
\text { of flat-topped and also rounded hills, with dark shallow porous loamy } \\
\text { soils, friable clays, shallow cracking clays and red friable earths all often } \\
\text { very stony }\end{array}$ & 26 & 7 & 14 \\
\hline $\begin{array}{l}\text { Cd3 Steep hilly to mountainous land: chief soils are leached sands and } \\
\text { siliceous sands on sandstones; grey cracking clays on shales; and shallow } \\
\text { red clays on basalt }\end{array}$ & 26 & 7 & 6 \\
\hline $\begin{array}{l}\text { Qd5 Hilly: hilly slopes of hard-setting loamy soils with red and red } \\
\text { mottled clayey subsoils }\end{array}$ & 19 & 5.1 & 7 \\
\hline $\begin{array}{l}\text { Rh9 Steep to mountainous: chief soils seem to be friable brown soils with } \\
\text { friable red soils and other friable soils }\end{array}$ & 10 & 2.7 & 4 \\
\hline $\begin{array}{l}\text { Kb28 Low hilly terrain on basalts and sedimentary rocks: chief soils are } \\
\text { moderate and shallow forms of cracking clays on the slopes }\end{array}$ & 8 & 2.2 & 15 \\
\hline $\begin{array}{l}\text { Kb12 Gently rolling areas of the sub-coastal lowland (lees than } 400 \mathrm{ft} \\
\text { above sea level on altered basic rocks; maximum relief is } 50 \mathrm{ft} \text { between } \\
\text { crests and valleys: chief soils are shallow dark cracking clays with hard } \\
\text { neutral red and yellow soils }\end{array}$ & 5 & 1.3 & 6 \\
\hline $\begin{array}{l}\text { Mg26 Plateaux and plateau remnants in mountainous country at moderate } \\
\text { elevation }(1000 \mathrm{ft}) \text { : rolling hills of red friable porous earths and/or brown } \\
\text { friable porous earths }\end{array}$ & 2 & 0.5 & 3 \\
\hline $\begin{array}{l}\text { Mw30 Gently undulating area of tertiary sediments and igneous rocks: } \\
\text { chief soils are red earths with associated friable earths }\end{array}$ & 2 & 0.5 & 2 \\
\hline $\begin{array}{l}\text { Sj12 Lower to middle reaches of stream flood-plains: chief soils are hard } \\
\text { acidic yellow and yellow mottled soils on flat areas and leached sands on } \\
\text { low broad sandy banks }\end{array}$ & 1 & 0.3 & 1 \\
\hline
\end{tabular}


Table 7. Moreton Basin Province: Pre-clearing vegetation.

\begin{tabular}{|c|c|c|c|}
\hline Vegetation Type & $\begin{array}{l}\text { No. of } \\
\text { Sites }\end{array}$ & $\begin{array}{l}\% \text { of } \\
\text { Total }\end{array}$ & $\begin{array}{c}\text { Rank by } \\
\text { Area }\end{array}$ \\
\hline H19 WOODLANDS Spotted gum/narrow-leaved ironbark woodland & 119 & 32 & 13 \\
\hline E10 WOODLANDS Blue gum flats, without grey ironbark & 82 & 22 & 8 \\
\hline $\begin{array}{l}\text { I13 WOODLANDS Narrow-leaved ironbark/blue gum woodland on } \\
\text { lower hillslopes }\end{array}$ & 32 & 8.6 & 12 \\
\hline H29 WOODLANDS Broad-leaved ironbark woodland & 29 & 7.8 & 16 \\
\hline H39 WOODLANDS Nerang-Beenleigh Alliance & 20 & 5.4 & 10 \\
\hline $\begin{array}{l}\text { E9 WOODLANDS Blue gum flats, often with grey ironbark, in near- } \\
\text { coastal areas }\end{array}$ & 18 & 4.8 & 15 \\
\hline $\begin{array}{l}\text { G32 WOODLANDS Narrow-leaved ironbark/silver-leaved } \\
\text { ironbark/yellow box woodland, without white box }\end{array}$ & 16 & 4.3 & 17 \\
\hline $\begin{array}{l}\text { H25 WOODLANDS White mahogany/brown bloodwood/smudgee } \\
\text { woodland on the Helidon Hills }\end{array}$ & 15 & 4 & 9 \\
\hline $\begin{array}{l}\text { G18 CLOSED FORESTS Araucarian microphyll vine forest of native } \\
\text { olive, white tamarind, small-leaved tuckeroo, deep yellowwood, lignum- } \\
\text { vitae, stinging trees, with emergent hoop and bunya pine }\end{array}$ & 12 & 3.2 & 19 \\
\hline $\begin{array}{l}\text { H1 CLOSED-FORESTS Semi-evergreen vine thicket communities } \\
\text { (softwood scrub) of rosewood, brush poison tree, brush wilga, leopard } \\
\text { ash, brush whitewood, small-fruited mock olive, small-leaved coondoo, } \\
\text { with frequent emergent narrow-leaved bottle tree and occasional brigalow } \\
\text { and belah }\end{array}$ & 7 & 1.9 & 11 \\
\hline $\begin{array}{l}\text { H5 CLOSED FORESTS Microphyll vine forest of small-leaved tuckeroo, } \\
\text { yellow tulip, python tree, silver croton, brush caper berry }\end{array}$ & 5 & 1.3 & 14 \\
\hline J16 WOODLANDS Gum-topped iron-bark communities & 4 & 1.1 & 18 \\
\hline $\begin{array}{l}\text { I11 WOODLANDS Narrow-leaved ironbark/silver-leaved ironbark } \\
\text { woodland }\end{array}$ & 4 & 1.1 & 3 \\
\hline $\begin{array}{l}\text { G3 CLOSED FORESTS Araucarian notophyll vine forest of white } \\
\text { booyong, rose marara, giant stinging tree, lignum-vitae, crows ash, with } \\
\text { emergent hoop pine }\end{array}$ & 2 & 0.5 & 6 \\
\hline $\begin{array}{l}\text { G31 WOODLANDS Narrow-leaved ironbark/yellow box woodland, with } \\
\text { white box }\end{array}$ & 2 & 0.5 & 4 \\
\hline H36 WOODLANDS Narrow-leaved red gum/pink bloodwood woodland & 1 & 0.3 & 7 \\
\hline $\begin{array}{l}\text { J17 WOODLANDS Thin-leaved stringybark/grey gum/narrow-leaved } \\
\text { ironbark woodland on coarse sands }\end{array}$ & 1 & 0.3 & 5 \\
\hline $\begin{array}{l}\text { H21 WOODLANDS Grey gum/broad-leaved white mahogany/grey } \\
\text { ironbark woodland }\end{array}$ & 1 & 0.3 & 2 \\
\hline $\begin{array}{l}\text { H47 CLOSED FORESTS Open-forest to woodland of brigalow and } \\
\text { wilga, with emergent belah and bottle trees }\end{array}$ & 1 & 0.3 & 1 \\
\hline
\end{tabular}


Table 8. Moreton Basin Province: Elevation in $25 \mathrm{~m}$ contour intervals.

\begin{tabular}{|c|c|c|c|c|}
\hline Elevation (m) & No. of Sites & $\%$ of Total & No. of Contours & Rank \\
\hline 0 & 2 & 0.5 & 9 & 19 \\
\hline 25 & 46 & 12.4 & 27 & 24 \\
\hline 50 & 84 & 22.6 & 68 & 23 \\
\hline 75 & 50 & 13.4 & 100 & 22 \\
\hline 100 & 32 & 8.6 & 116 & 21 \\
\hline 125 & 22 & 5.9 & 118 & 18 \\
\hline 150 & 29 & 7.8 & 119 & 20 \\
\hline 175 & 18 & 4.8 & 147 & 16 \\
\hline 200 & 7 & 1.9 & 161 & 10 \\
\hline 225 & 7 & 1.9 & 149 & 11 \\
\hline 250 & 7 & 1.9 & 129 & 13 \\
\hline 275 & 3 & 0.8 & 155 & 4 \\
\hline 300 & 2 & 0.5 & 137 & 2 \\
\hline 325 & 15 & 4 & 106 & 17 \\
\hline 350 & 10 & 2.7 & 104 & 15 \\
\hline 375 & 7 & 1.9 & 121 & 14 \\
\hline 400 & 1 & 0.3 & 97 & 1 \\
\hline 425 & 4 & 1.1 & 99 & 9 \\
\hline 450 & 3 & 0.8 & 87 & 8 \\
\hline 475 & 2 & 0.5 & 83 & 5 \\
\hline 500 & 1 & 0.3 & 67 & 3 \\
\hline 525 & 0 & 0 & 53 & 0 \\
\hline 550 & 2 & 0.5 & 40 & 12 \\
\hline 575 & 1 & 0.3 & 41 & 6 \\
\hline 600 & 1 & 0.3 & 35 & 7 \\
\hline 625 & 0 & 0 & 29 & 0 \\
\hline 650 & 0 & 0 & 20 & 0 \\
\hline 675 & 0 & 0 & 18 & 0 \\
\hline 700 & 0 & 0 & 11 & 0 \\
\hline 725 & 0 & 0 & 6 & 0 \\
\hline 750 & 0 & 0 & 3 & 0 \\
\hline 775 & 0 & 0 & 2 & 0 \\
\hline 800 & 0 & 0 & 2 & 0 \\
\hline 825 & 0 & 0 & 2 & 0 \\
\hline 850 & 0 & 0 & 2 & 0 \\
\hline
\end{tabular}


Table 9. Moreton Basin Province: Stream order and site distribution.

\begin{tabular}{|c|r|r|r|r|}
\hline Stream Order & No. of Sites & \% of Total Sites & No. of Streams & Rank \\
\hline 1 & 232 & 62.4 & 723 & 6 \\
\hline 2 & 70 & 18.8 & 349 & 4 \\
\hline 3 & 41 & 11 & 234 & 2 \\
\hline 4 & 17 & 4.6 & 85 & 3 \\
\hline 5 & 6 & 1.6 & 25 & 5 \\
\hline 6 & 6 & 1.6 & 44 & 1 \\
\hline
\end{tabular}

Table 10. Moreton Basin Province: Distance of sites to streams.

\begin{tabular}{|c|c|c|}
\hline $\begin{array}{c}\text { Distance } \\
(\mathbf{m})\end{array}$ & $\begin{array}{c}\text { No. } \\
\text { of } \\
\text { Sites }\end{array}$ & $\begin{array}{c}\text { \%o of } \\
\text { Total } \\
\text { Sites }\end{array}$ \\
\hline $0-100$ & 101 & 27.2 \\
\hline $100-200$ & 83 & 22.3 \\
\hline $200-300$ & 56 & 15.1 \\
\hline $300-400$ & 46 & 12.4 \\
\hline $400-700$ & 54 & 14.5 \\
\hline $700-1050$ & 16 & 4.3 \\
\hline$>1050$ & 16 & 4.3 \\
\hline
\end{tabular}

\section{Grid Analysis of Environmental Variables and Site Distribution}

The grid analysis builds on the polygon overlay analysis. Geology, soils, and pre-clearing vegetation were converted to $250 \mathrm{~m}$ grid cell layers for the entire Moreton Basin. The grid layers consisted of a regular lattice of square cells, and were associated with alphanumeric/numeric environmental and site number codes (see Tables 5,6 and 7) and numbers of cells per code. A simple grid function (geology + soils + vegetation $=$ output site potential grid) defined an output grid of site potential specified in three classes (high, medium, low). The classes were determined by the "natural breaks' method that identifies groupings and patterns in the data (ArchView GISC Version 3.x default).

Figure 10 shows the high class has a strong relationship to Geology 865, and Vegetation H19. Medium shows various combinations of Geology 3975 and Vegetation H19 and E10. Low shows other combinations of site potential environmental variables. Low site potential is represented by approximately $17 \%$ of the total number of sites on the Indigenous Sites Database.

Distance to water $(<200 \mathrm{~m})$ was added to the grid analysis (Figure 11). The results show that scale is a major factor in predicting the location of sites and distance to water is a variable that can be used to refine the levels of site prediction.

\section{Discussion}

Using the Moreton Basin Province as a test case we have correlated sites recorded on the ISD with a range of basic environmental variables. Archaeological sites in the Moreton Basin Province were found to occur most commonly below $100 \mathrm{~m}$ elevation and within $200 \mathrm{~m}$ of water, within the Quaternary floodplains and river terraces associated with (pre-clearing) spotted gum/narrow-leaved ironbark woodland and blue gum flats woodland. However, as implied and discussed throughout this paper, we do not currently know if this is a real pattern or one created by recorder bias, or a combination of factors. The type and distribution of sites identified in the Moreton Basin Province may reflect a representative pattern, although this is unlikely. It is also unlikely that the type and distribution of sites in this province are representative of other provinces in the bioregion, but currently we have no way of testing this argument. We also suspect there is an intraprovince bias in the recording of sites but currently do not have the means to identify this suspicion. We also need to review and incorporate ethnohistorical data and other sources of information to develop models of a more explanatory nature and to field-test the model. It is hoped that consultants undertaking Environmental Impact Assessments in this province will utilise the model to develop a better understanding of the area. Comparative studies of provinces and bioregions need to be developed to further test the results achieved here.

\section{Conclusion}

In order to manage cultural heritage places, we need to know where they are, what their characteristics are, and the range of potential human and environmental impacts on these sites. A government with a serious commitment to protecting cultural heritage places should have as part of its structure a professional unit which records and assesses cultural heritage sites, maintains a comprehensive database, develops management plans and monitors cultural heritage sites. Examples exist worldwide where this is the case (e.g. Hester 1994). Professional staff in these institutions should take an active role in field research, management and monitoring and of course policy development. Meaningful strategic surveys and management directions can be developed and relevant policies formulated as a result of such work. Unfortunately, with respect to Indigenous heritage sites in Queensland, this professional structure has not been developed and in fact some of the potentially promising directions developed in the 1980s have stalled. 


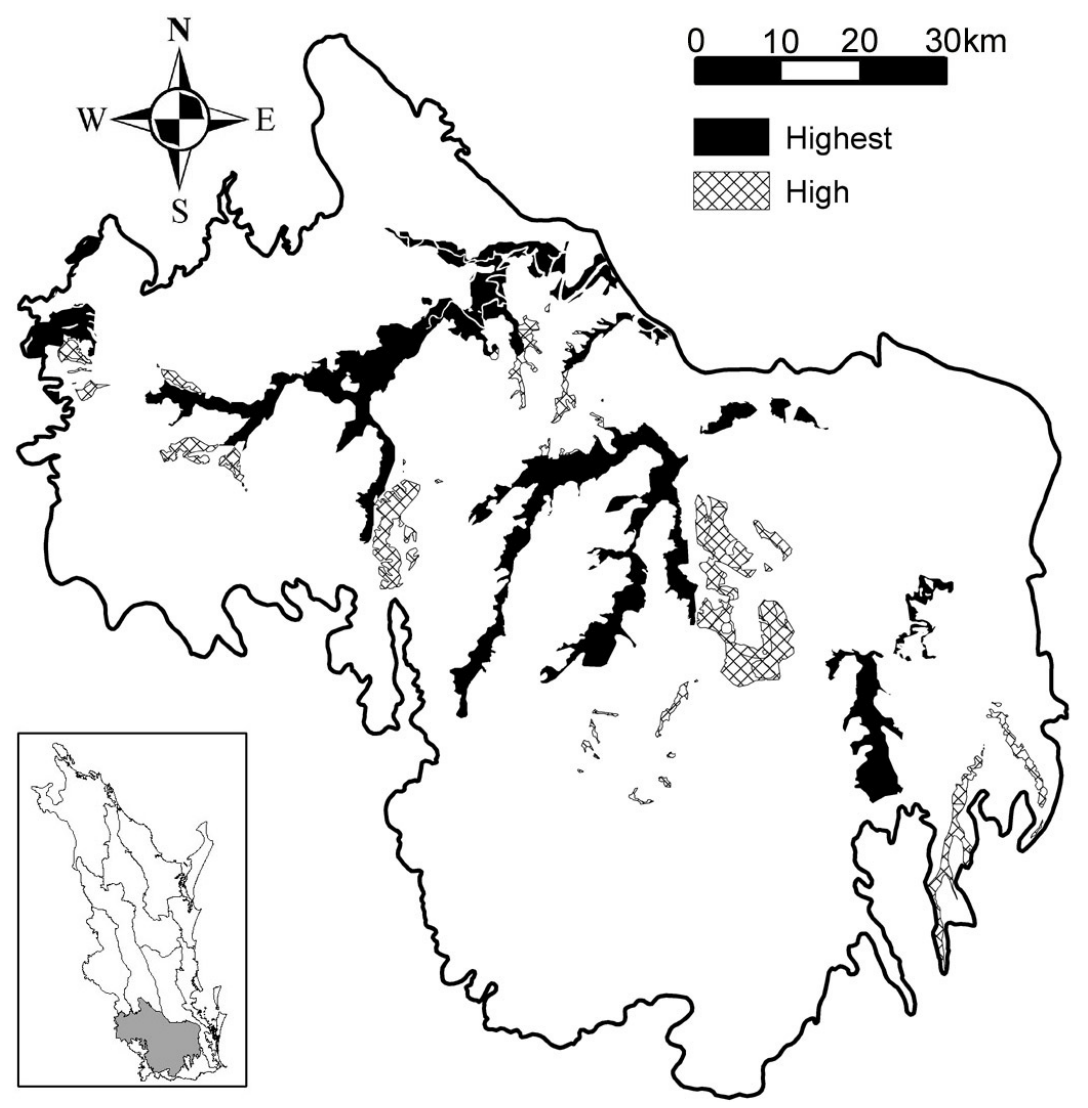

Figure 9. Moreton Basin Province: Results of geology, soils and vegetation polygon overlay and the highest number of known archaeological sites.

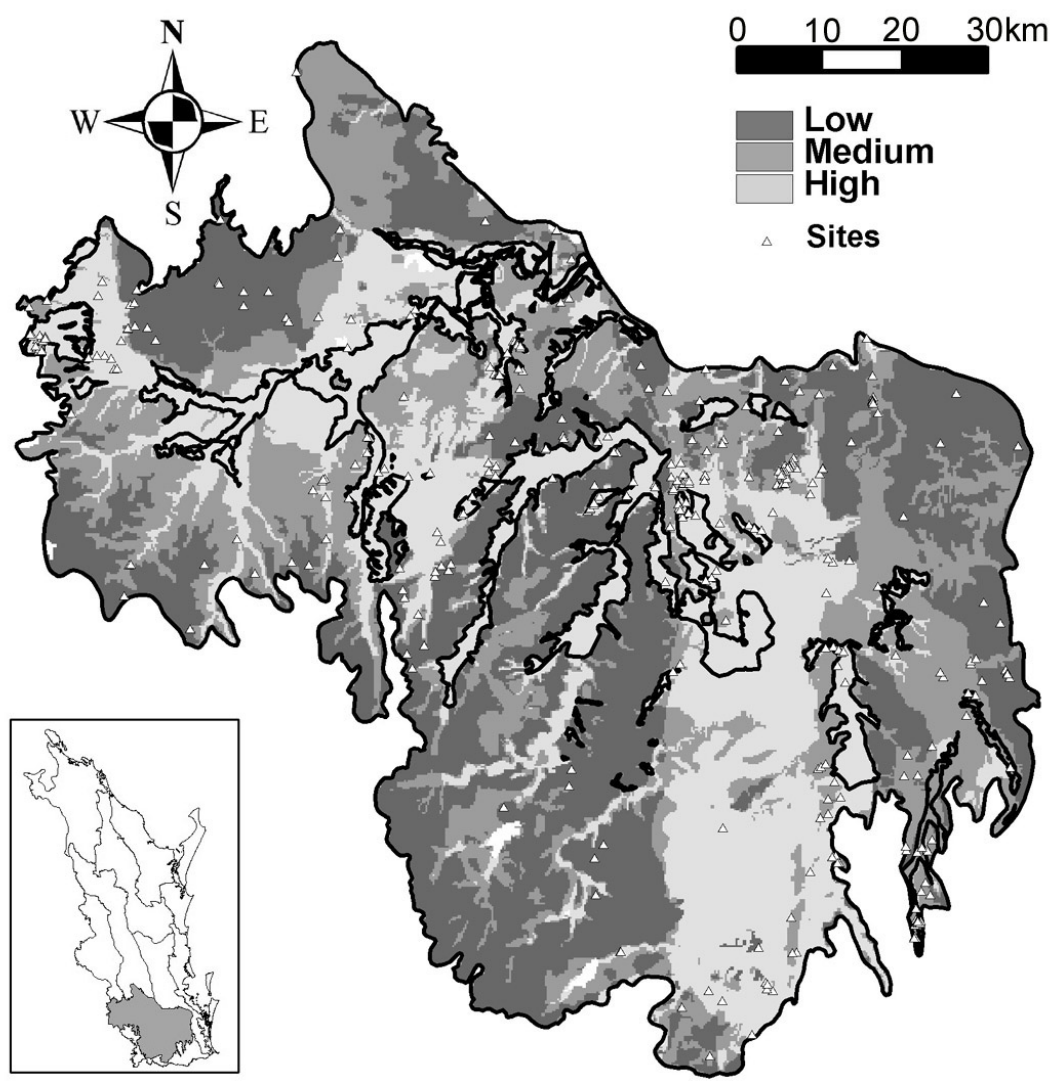

Figure 10. Moreton Basin Province: Results of $250 \mathrm{~m}$ grid cell analysis for geology, soils and vegetation. 


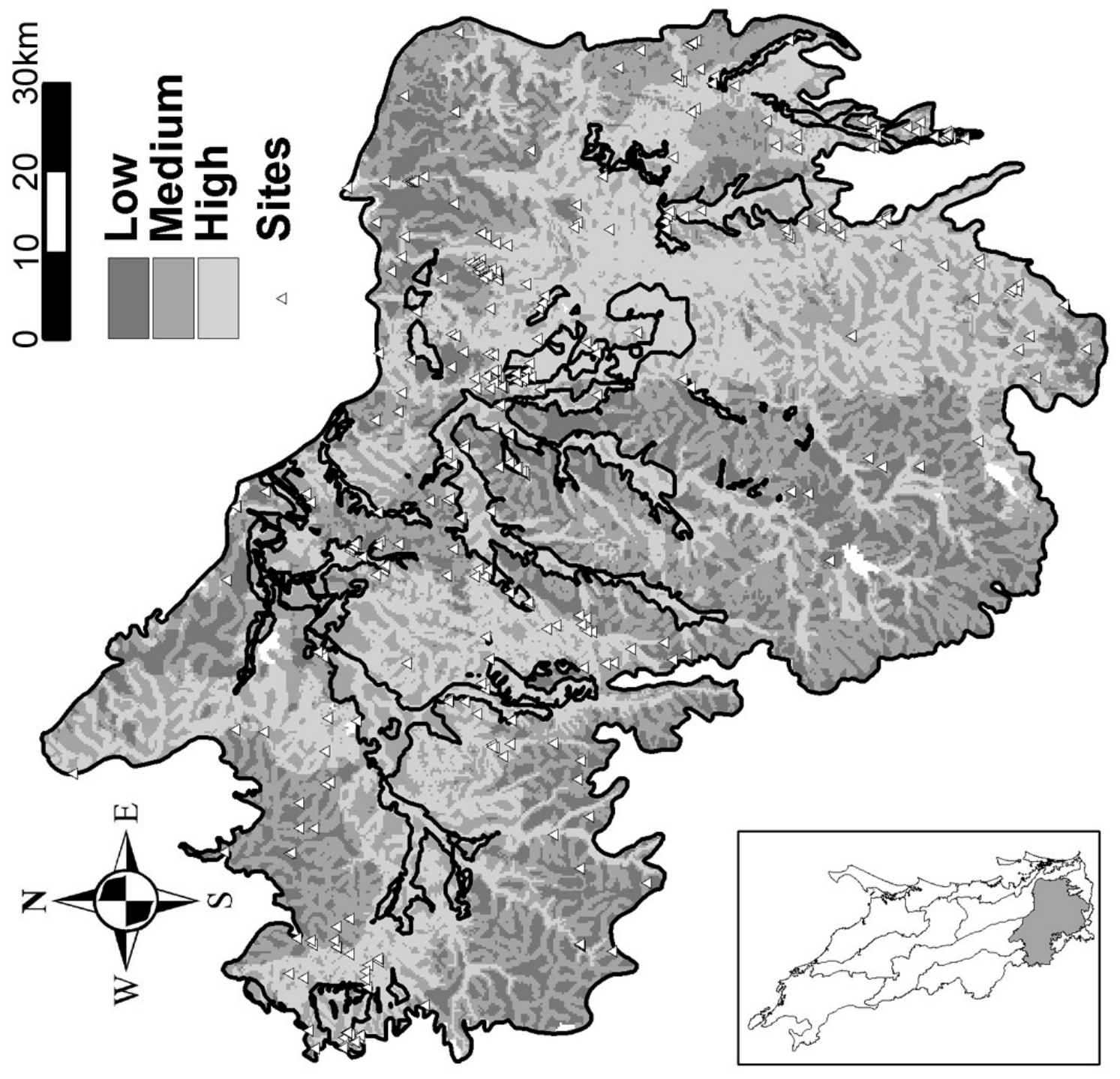

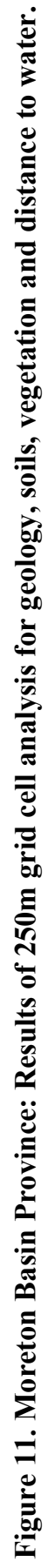


We maintain that the Queensland bioregions provide a useful first-order level of analysis for describing the archaeological record of Queensland. Although conclusions that can be derived at this level of analysis are very broad it is possible to identify regional differences in archaeological knowledge, the scale of regional impacts and levels of management required. However, in order to develop these analyses further bioregional reviews of the kind developed previously for the MGDs and DUs need to be undertaken which utilise a wider range of information than we have been able to address in this paper.

For the same reasons, provinces within the respective bioregions also provide a useful level of analysis but again it would be necessary to provide a more detailed level of analysis of each province than has been undertaken in this paper. Having attempted to develop a predictive model for the Moreton Basin Province we have some sympathy with the view that predictive modelling can be a time consuming and expensive exercise to discover the obvious. Equally, however, we believe that the model that we have attempted to develop here can greatly be improved by:

- assessing the locational accuracy of the sites so far recorded;

- discriminating between the site types recorded;

- reviewing and incorporating ethnohistorical data and other sources of information; and, most importantly,

- testing the model in the field.

While we have not at this stage been able to develop a predictive model of high resolution we have as a minimum indicated areas of potential site sensitivity that should be useful for cultural heritage management issues and hopefully for stimulating further research in the area. Research and cultural heritage studies and assessments that take advantage of this initial modelling should be able to feed environmental and site data back into the model and thus modify it as required. Most importantly we have demonstrated that the Indigenous Sites Database is now sufficiently organised and maintained and that GIS layers are available that can be used to increasingly develop more complex models. With the addition of ethnohistorical data and other sources of information we can move towards developing models of a more explanatory nature than we have been able to achieve so far.

\section{Acknowledgements}

We would firstly like to thank Sean Ulm and Jay Hall for organising the Southeast Queensland Symposium and giving us the opportunity to present this paper. We also acknowledge feedback received from those attending the symposium. In preparing the paper for publication we are particularly grateful to Sean Ulm and Mal Ridges (National Parks and Wildlife Service, New South Wales) who as editor and reviewer both went beyond the call of duty in their thoroughness. We also thank Cameron Harvey for his comments. We hope to have satisfied most of their concerns but remain responsible for any errors or omissions.

\section{References}

Altschul, J.H. 1988 Models and the modelling process. In W.J. Judge and L. Sebastian (eds), Quantifying the Present and Predicting the Past: Theory, Method, and Application of Archaeological Predictive Modeling, pp.61-96. Denver: United States Department of the Interior, Bureau of Land Management.
Berndt, R.M. and C.H. Berndt 1977 The World of the First Australians. $2^{\text {nd }}$ ed. Sydney: Ure Smith.

Binford, L.R. 1964 A consideration of archaeological research design. American Antiquity 29:425-441.

Binford, L.R. 1992 Seeing the present and interpreting the past and keeping things straight. In J. Rossignol and L. Wandsnider (eds), Space, Time and Archaeological Landscapes, pp.43-59. New York: Plenum Press.

Birdsell, J.B. 1953 Some environmental and cultural factors influencing the structuring of Australian Aboriginal populations. American Naturalist 87:171-207.

Birdsell, J.B. 1957 Some population problems involving Pleistocene man. Cold Spring Harbor Symposia on Quantitative Biology 22:47-68.

Birdsell, J.B. 1968 Some predictions for the Pleistocene based on equilibrium systems among recent hunter-gatherers. In R.B Lee and I. DeVore (eds), Man the Hunter, pp.229-240. Chicago: Aldine Publishing Company.

Birdsell, J.B. 1971 Ecology, spacing mechanisms and adaptive behaviour in Aboriginal land tenure. In R.G. Crocombe (ed.) Land Tenure in the Pacific, pp.334-361. Melbourne: Oxford University Press.

Birdsell, J.B. 1977 The recalibration of a paradigm for the first peopling of Australia. In J. Allen, J. Golson. and R. Jones (eds), Sunda and Sahul: Prehistoric Studies in Southeast Asia, Melanesia and Australia, pp.113-167. London: Academic Press.

Blain, H.D. and J.R. Davis 1984 An archaeological site potential map of Australia. CSIRO Technical Memorandum 4-84/28. Canberra: CSIRO, Institute of Biological Resources, Division of Water and Land Resources.

Border, A. 1992 An Archaeological Study in the Central Downs Sub-Region of the Mitchell Grass Downs Biogeographic Zone, Queensland. Unpublished report to the Department of Environment and Heritage, Brisbane and Australian Heritage Commission, Canberra.

Border, A. and M.J. Rowland 1990 The Mitchell Grass Downs Biogeographical Zone (Queensland): A Heritage Resource Assessment. Unpublished report to the Department of Environment and Heritage, Brisbane and Australian Heritage Commission, Canberra.

Bowdler, S. 1981 Unconsidered trifles?: Cultural resource management, environmental impact statements and archaeological research in New South Wales. Australian Archaeology 12:123-133.

Bowdler, S. 1983 Aboriginal Sites on the Crown-Timber Lands of New South Wales: A Report to the Forestry Commission of New South Wales. Sydney: Government Printer.

Bowdler, S. 1984 Archaeological significance as a mutable quality. In S. Sullivan and S. Bowdler (eds), Site Surveys and Significance Assessment in Australian Archaeology, pp.1-9. Canberra: Department of Prehistory, Research School of Pacific Studies, Australian National University.

Butzer, K.W. 1971 Environment and Archaeology. Chicago: Aldine-Atherton.

Butzer, K.W. 1982 Archaeology as Human Ecology. Cambridge: Cambridge University Press.

Cane, S. 1997 A Coastal Heritage. Canberra: Australian Heritage Commission.

Clarke, D.L. 1968 Analytical Archaeology. London: Methuen and Co. Ltd.

Coones, P. 1992 The unity of landscape. In L. Macinnes and C.R. Wickham-Jones (eds), All Natural Things: Archaeology and the Green Debate, pp.22-40. Oxbow Monograph 21. Oxford: Oxbow Books. 
Davidson, D.S. 1928 The chronological aspects of certain Australian social institutions as inferred from geographical distribution. Philadelphia: University of Philadelphia.

Dixon, R.M.W. 1976 Tribes, languages and other boundaries in northeast Queensland. In N. Peterson (ed.), Tribes and Boundaries in Australia, pp.207-238. Canberra: Australian Institute of Aboriginal Studies.

Dunnell, R.C. 1992 The notion of site. In J. Rossignol and L. Wandsnider (eds), Space, Time and Archaeological Landscapes, pp.21-41. New York: Plenum Press.

Ebert, J.I. 2000 The state of the art in "inductive" predictive modelling: Seven big mistakes (and lots of smaller ones). In K.L. Wescott and R.J. Brandon (eds), Practical Applications of GIS for Archaeologists: A Predictive Modelling Toolkit, pp.129-134. London: Taylor and Francis.

Ellis, B. 1994 Rethinking the Paradigm: Cultural Heritage Management in Queensland. Ngulaig 10. Brisbane: Aboriginal and Torres Strait Islander Studies Unit, University of Queensland.

Elkin, A.P. 1964 The Australian Aborigines. New York: Doubleday.

Flood, J. 1984 More or less significant: A national perspective on assessing the significance of archaeological sites. In S. Sullivan and S. Bowdler (eds), Site Surveys and Significance Assessment in Australian Archaeology, pp.55-60. Canberra: Department of Prehistory, Research School of Pacific Studies, Australian National University.

Gaffney, V. and M. van Leusen 1995 Postscript - GIS, environmental determinism and archaeology: A parallel text. In G. Lock and Z. Stancic (eds), Archaeology and Geographical Information Systems: A European Perspective, pp.367-381. London: Taylor and Francis.

Godwin, L., M.J. Morwood, S. L'Oste-Brown and A. Dale 1999 Bowen Basin Aboriginal cultural heritage project: A strategic regional approach for research and management. Australian Archaeology 48:29-34.

Hester, H.A. 1994 A State Plan for the Conservation of Archaeological Resources in Arkansas. Little Rock: Arkansas Archaeological Survey.

Howitt, A.W. 1889 On the organization of Australian tribes. Transactions of the Royal Society of Victoria 1:96-137.

Hughes, P.J. and M.E. Sullivan 1982 Geoarchaeology in Australia: A review. In W. Ambrose and P. Duerden (eds), Archaeometry: An Australian Perspective, pp.100-111. Canberra: Department of Prehistory, Research School of Pacific Studies, Australian National University.

Hughes, P.J. and M.E. Sullivan 1984 Environmental approaches to assessing significance. In S. Sullivan and S. Bowdler (eds), Site Surveys and Significance Assessment in Australian Archaeology, pp.34-47. Canberra: Department of Prehistory, Research School of Pacific Studies, Australian National University.

Johnston, H. and M.J. Rowland 1987 Representativeness, Conservation and the Archaeology Branch (Queensland) Site Register. Unpublished report to the Archaeology Branch, Department of Community Services, Brisbane.

Judge, W.J., J.I. Ebert and R.K. Hitchcock 1975 Sampling in regional archaeological surveys. In W.J. Mueller (ed.), Sampling in Archaeology, pp.82-123. Tucson: University of Arizona Press.

Judge, W.J. and D.W. Martin 1988 An appraisal. In W.J. Judge and L. Sebastian (eds), Quantifying the Present and Predicting the Past: Theory, Method, and Application of Archaeological Predictive Modeling, pp.571-580. Denver: United States Department of the Interior, Bureau of Land Management.
Judge, W.J. and L. Sebastian (eds) 1988 Quantifying the Present and Predicting the Past: Theory, Method, and Application of Archaeological Predictive Modeling. Denver: United States Department of the Interior, Bureau of Land Management.

Kincaid, C. 1988 Predictive modelling and its relationship to cultural resource management applications. In W.J. Judge and L. Sebastian (eds), Quantifying the Present and Predicting the Past: Theory, Method, and Application of Archaeological Predictive Modeling, pp.549-569. Denver: United States Department of the Interior, Bureau of Land Management.

Kohler, T.A. 1988 Predictive locational modelling: History and current practice. In W.J. Judge and L. Sebastian (eds), Quantifying the Present and Predicting the Past: Theory, Method, and Application of Archaeological Predictive Modeling, pp.19-59. Denver: United States Department of the Interior, Bureau of Land Management.

Kohler, T.A. and S.C. Parker 1986 Predictive models for archaeological resource location. Advances in Archaeological Method and Theory 9:397-452. New York: Academic Press.

Kvamme, K.L. 1988 Using existing archaeological survey data for model building. In W.J. Judge and L. Sebastian (eds), Quantifying the Present and Predicting the Past: Theory, Method, and Application of Archaeological Predictive Modeling, pp.301-323. Denver: United States Department of the Interior, Bureau of Land Management.

McCarthy, F. 1940 Catalogue of the Aboriginal relics of New South Wales. Mankind 3:91-99, 121-127, 149-154, 181-188, 199-206.

Morgan, M.G. and J. Terrey 1990 Natural regions of western New South Wales and their use for environmental management. Proceedings of the Ecological Society of Australia 16(4):67-73.

Mulvaney, D.J. 1975 The Prehistory of Australia. Rev. ed. Sydney: Penguin.

Peterson, N. 1976 The natural and cultural areas of Aboriginal Australia. In N. Peterson (ed.), Tribes and Boundaries in Australia, pp.50-71. Social Anthropology Series 10. Canberra: Australian Institute of Aboriginal Studies.

Ross, A. 1981 Holocene environments and prehistoric site patterning in the Victorian Mallee. Archaeology in Oceania 16(3):145-154.

Rowland, M.J. 1984 Clean up your own backyard first!: Problems and complexities in archaeological resource management - Stradbroke and Moreton Islands. In R.J. Coleman, J. Covacevich and P. Davis (eds), Focus on Stradbroke: New Information on North Stradbroke Island and Surrounding Areas, 1974-1984, pp.44-53. Brisbane: Booralong Publications.

Rowland, M.J. 1986 Archaeological research, site recording, and management, Archaeology Branch, Department of Community Services, Brisbane. Australian Archaeology 23:105-114.

Rowland, M.J. 1989 The current state of the site files, Department of Community Services, Queensland. In J. Flood, I. Johnson and S. Sullivan (eds), Sites and Bytes: Recording Aboriginal Places in Australia, pp.262-294. Special Australian Heritage Publication Series 8. Canberra: Australian Government Publishing Service.

Rowland, M.J. 1991 Getting organized: Recording of Aboriginal art sites in Queensland, Australia. In C. Pearson and B.K. Swartz (eds), Rock Art and Posterity: Conserving, Managing and Recording Rock Art, pp.124-136. Occasional AURA Publication 4. Melbourne: Australian Rock Art Research Association. 
Rowland, M.J. 1995 Aboriginal prehistoric sites: Identifying and assessing significance. In S. Sullivan (ed.), Cultural Conservation: Towards a National Approach, pp.357-367. Special Australian Heritage Publication Series 9. Canberra: Australian Government Publishing Service.

Rowland, M.J., A. Border and J. Smith 1994 Archaeological research and management: A biogeographical approach. Australian Archaeology 38:23-28.

Sattler, P.S. 1986 Nature conservation in Queensland: Planning the matrix. Proceedings of the Royal Society of Queensland 97:1-21

Sattler, P.S. 1999 Introduction. In P.S. Sattler and R.D Williams (eds), The Conservation Status of Queensland's Bioregional Ecosystems, pp.1-19. Brisbane: Environmental Protection Agency.

Sattler, P.S. and R.D. Williams (eds) 1999 The Conservation Status of Queensland's Bioregional Ecosystems. Brisbane: Environmental Protection Agency.

Sebastian, L. and W.L. Judge 1988 Predicting the past: Correlation, explanation, and the use of archaeological models. In W.J. Judge and L. Sebastian (eds), Quantifying the Present and Predicting the Past: Theory, Method, and Application of Archaeological Predictive Modeling, pp.1-18. Denver: United States Department of the Interior, Bureau of Land Management.

Smith, L. 1996 Significance concepts in Australian management archaeology. In L. Smith and A. Clarke (eds), Issues in Management Archaeology, pp.67-78. Tempus 5. St Lucia: Anthropology Museum, University of Queensland.

Smith, J.R. and M.J. Rowland 1991 The Desert Upland Biogeographical Zone (Queensland): A Heritage Resource Assessment. Unpublished report to the Department of Environment and Heritage, Brisbane and Australian Heritage Commission, Canberra.

Stanton, J.P. and M.G. Morgan 1977 Report No 1: The Rapid Selection and Appraisal of Key Endangered Sites: The Queensland Case Study. Unpublished report to the Department of Environment, Housing and Community Development, University of New England, School of Nature Resources, Armidale.
Stanner, W.E.H. 1965 Aboriginal territorial organization. Oceania 36:1-26.

Sutcliffe, K.A. 1979 Cultural resource management in Queensland. In J.R. McKinlay and K.L. Jones (eds), Archaeological Resource Management in Oceania, pp.56-66. Wellington: New Zealand Historic Places Trust.

Thackway, R. and I.D. Cresswell 1995 An Interim Biogeographic Regionalisation for Australia: A Framework for Establishing the National System of Reserves, Version 4.0. Canberra: Australian Nature Conservation Agency.

Tindale, N.B. 1974 Aboriginal Tribes of Australia. Los Angeles: University of California Press.

Ulm, S., B. Barker, J. Hall, I. Lilley, I. McNiven, R. Neal and M.J Rowland 1995 Pre-European coastal settlement and use of the sea: A view from Queensland. Australian Archaeology 41:24-26.

Wescott, K.L. 2000 Introduction. In K.L. Wescott and R.J. Brandon (eds), Practical Applications of GIS for Archaeologists: A Predictive Modelling Toolkit, pp.1-4. London: Taylor and Francis.

Wills, A.K. 1976 The Granite and Traprock area of South East Queensland: A Land Inventory and Land Utilisation Study. Technical Bulletin 13. Brisbane: Department of Primary Industries, Division of Land Utilisation.

Witter, D. 1984 Providing a context for management archaeology. In S. Sullivan and S. Bowdler (eds), Site Surveys and Significance Assessment in Australian Archaeology, pp.48-54. Canberra: Department of Prehistory, Research School of Pacific Studies, Australian National University.

Young, P.A.R. and M.A. Cotterell 1993 A Conservation Assessment of the SEQ2001 Region. Brisbane: Conservation Strategy Branch, Division of Conservation, Queensland Department of Environment and Heritage.

Young, P.A.R. and H.A. Dillewaard 1999 Southeast Queensland. In P.S. Sattler and R.D Williams (eds), The Conservation Status of Queensland's Bioregional Ecosystems, pp.12/112/75. Brisbane: Environmental Protection Agency. 